\title{
Three new species of the armored catfish genus Loricaria (Siluriformes: Loricariidae) from river channels of the Amazon basin
}

\author{
Matthew R. Thomas ${ }^{1}$ and Lúcia H. Rapp Py-Daniel ${ }^{2}$
}

Three new species of Loricaria are described from large white- and black-water river channels of the Amazon basin of Brazil, the upper rio Negro drainage of southern Venezuela, and clear waters of the lower rio Tocantins. Loricaria spinulifera and L. pumila differ from other species of Loricaria by having unique patterns of abdominal plate development and hypertrophied odontodes forming conspicuous crests on dorsal surfaces of the head and predorsal plates. Both are small species of Loricaria, reaching sexual maturity at less than $120 \mathrm{~mm}$ SL, and exhibiting sexually dimorphic characters consistent with members of the L. cataphracta complex. Loricaria spinulifera differs from L. pumila in having a unique arrangement of buccal papillae and large thorn-like odontodes on the dorsum of the head. Loricaria pumila is the smallest known Loricaria, reaching sexual maturity at less than $80 \mathrm{~mm}$ SL. Loricaria lundbergi differs from other Loricaria by having a unique abdominal plate pattern, broad head, and small basicaudal plate. Loricaria lundbergi is sympatric with L. spinulifera in the lower rio Negro drainage, but is also known from the rio Baria system of the Casiquiare drainage. Loricaria pumila occurs in the lower rio Amazonas and lower rio Tocantins. All three new species exhibit varying degrees of reduction in eye size and pigmentation seen in other fishes inhabiting deep river channels of South America.

Três novas espécies de Loricaria são descritas provenientes dos canais de grandes rios de águas brancas e pretas da bacia Amazônica brasileira, da bacia do alto rio Negro no sul da Venezuela e das águas claras do baixo rio Tocantins. Loricaria lundbergi é simpátrica com L. spinulifera no baixo rio Negro, mas também é conhecida para o sistema do rio Baria, drenagem do Cassiquiare. Loricaria pumila ocorre no baixo rio Amazonas e baixo rio Tocantins. Loricaria spinulifera e L. pumila diferem de outras Loricaria por apresentarem odontódeos hipertrofiados formando cristas conspícuas nas superfícies dorsal da cabeça e placas pré-dorsais, olhos reduzidos em tamanho e sem o opérculo da íris, e um padrão único de desenvolvimento de placas abdominais. Ambas espécies são pequenas entre Loricaria, alcançando maturidade sexual com menos de 120 mm comprimento padrão, e exibindo caracteres sexualmente dimórficos consistentes com membros do complexo L. cataphracta. Loricaria spinulifera difere de L. pumila por apresentar um arranjo das papilas bucais único e presença de grandes odontódeos em forma de espinho no dorso da cabeça. Loricaria pumila é a menor Loricaria conhecida, alcançando maturidade sexual com menos de 80 mm comprimento padrão. Loricaria lundbergi difere de outras Loricaria por uma combinação única de configuração das placas abdominais, cabeça larga e pequena placa basicaudal. Todas as três novas espécies apresentam graus variados de redução de tamanho do olho e pigmentação distinta da observada em outros peixes que habitam os canais profundos dos rios da América do Sul.

Key words: Neotropical, Taxonomy, Loricariinae, Calhamazon, Rio Negro.

\footnotetext{
${ }^{1}$ Department of Zoology and Center for Systematic Biology, Southern Illinois University, Carbondale, Illinois 62901, USA. matt.thomas@ky.gov

${ }^{2}$ Instituto Nacional de Pesquisas da Amazônia, Programa de Coleções e Acervos, Coleção de Peixes, Av. André Araújo, 2936, Petrópolis, 69011-970 Manaus, AM, Brazil.rapp@inpa.gov.br
} 


\section{Introduction}

Loricaria Linnaeus, 1758, was the first loricariid taxon described with $L$. cataphracta as the type species. Although more than half of all species in the subfamily Loricariinae have been at some point assigned to Loricaria (Isbrücker, 1981), most of these have since been transferred to other genera. In a review of the genus, Isbrücker (1981) recognized Loricaria (sensu stricto) to be comprised of eleven species and two undescribed forms distributed in the Amazon, Orinoco, Paraguay, Paraná, and smaller coastal rivers draining the Guyana and Brazilian Shields.

Loricaria species are most readily distinguished from other loricariine genera based on the presence of elongate, slender filaments on the lips and a low number of bicuspid premaxillary teeth (usually three to four per side) that are about twice the length of the dentary teeth. Loricaria, as diagnosed by Isbrücker (1981) on the basis of external morphology, was shown to be monophyletic by Rapp Py-Daniel (1997) based on additional osteological synapomorphies, including palatine, pharyngeal plate, pelvic girdle, and sensory canal morphology. In a recent phylogenetic assessment of the Loricariinae, based on combined analysis of molecular and morphological data sets, Covain et al. (2008) confirmed the monophyly of several morphologically diagnosed groups within the Loricariini, including the Loricaria group and the closely related Pseudohemiodon group; however, species diversity, geographic distributions and interrelationships within Loricaria are poorly understood and are currently under investigation by the senior author.

Ferraris (2007) listed nine valid Loricaria species. However, 12 nominal Loricaria species were recognized by Rodríguez \& Miquelarena (2003) and Covain \& Fisch-Muller (2007). In addition to that, several undescribed species have been recently identified in museum collections (pers. obs.). Three new species are formally described herein, mostly from specimens collected via benthic trawls in deep river channels of the Negro and middle and lower Amazon basin as part of the "Calhamazon project" (Cox Fernandes et al., 2004). We recognize these new species as members of Loricaria based on the presence of shared morphological characters described above as diagnostic for the genus.

\section{Material and Methods}

Institutional acronyms follow Leviton et al. (1985), dr. indicates drainage, and $c \& s$ indicates cleared and stained specimens. Morphometric data were taken from 125 specimens of Loricaria, including 31 representing three new species described herein, and 94 representing nominal species for comparison. Measurements were made with digital calipers to the nearest $0.1 \mathrm{~mm}$. Most measurements were derived from Isbrücker \& Nijssen (1978) and Boeseman (1971), including 25 point-to-point distances (Fig. 1). The following distances are expressed as percentages of either standard length (SL) or head length (HL): 1, standard length (SL) - tip of snout to end of caudal peduncle; 2, snout length - tip of snout to anterior bony orbit (in HL); 3, head length - tip of snout to posterior tip of parieto-supraoccipital process (in SL); 4, minimum orbital diameter - anterior to posterior bony rim of orbit, excluding posterior notch (in HL); 5, maximum orbital diameter - anterior to posterior bony rim of orbit, including posterior notch (in HL); 6, predorsal length - tip of snout to dorsalfin origin (in SL); 7, dorsal spine length - proximal origin to distal tip (in SL); 8, head depth - at posterior tip of parietosupraocciptal process (in HL); 9, body depth - at point just anterior to dorsal spine origin (in SL); 10, pectoral spine length - proximal origin to distal tip (in SL); 11, pelvic spine length proximal origin to distal tip (in SL); 12, anal spine length proximal origin to distal tip (in SL); 13, post-dorsal length insertion of last dorsal-fin ray to end of caudal peduncle (in SL); 14, post-anal length - insertion of last anal-fin ray to end of caudal peduncle (in SL); 15, caudal peduncle depth - least depth (usually at second lateral plate anterior to caudal fin base (in HL); 16, head width - at lateral margin of opercle (in SL); 17, body width - at posterior tip of cleithral process (in SL); 18 , left to right posterior bony rim of nostrils (in HL); 19 , posterior margin left bony nostril to medial right orbit margin at frontal-sphenotic juncture (in HL); 20, interorbital distance - at frontal-sphenotic juncture (in HL); 21, medial left orbit margin at frontal-sphenotic juncture to posterior tip of parietosupraoccipital process (in HL); 22, body width - at dorsal spine origin (in SL); 23, body width - at anal-fin origin (in SL); 24 , abdominal length - between origins of pelvic and anal fins (in SL); 25, thoracic length - between origins of pectoral and pelvic fins (in SL); 26, basicaudal plate length - anterior base to posterior tip of elongate triangular plate on base of caudal fin (in HL).

Meristic data were obtained from 31 specimens representing three new species described herein, and 187 representing nominal species for comparison. Meristic methods and terminology follow Isbrücker \& Nijssen (1978) in part; dermal plate terminology follows Schaefer (1997). Bilaterally paired features were counted on the left side of the body when possible; in cases of broken or damaged features on the left side, counts were made on the right side. Counts of plates in the lateral series include total lateral plates and coalesced lateral plates. Total lateral plates include those in the median series bearing two parallel odontode keels beginning with the first plate posterior to the cleithrum (bearing a single odontode ridge) and ending with the last plate at end of caudal peduncle, not counting the basicaudal plate. Coalesced lateral plates include those in the lateral series beginning with the first plate on which the dorsal and ventral odontode keels meet and continue parallel to each other to the end of the caudal peduncle. Post-anal plates include those between the anal-fin insertion and end of caudal peduncle. Abdominal plates are divided into median abdominal and lateral abdominal series. Lateral abdominal plates are the paired series of oblong or rectangular large plates situated between the pec- 

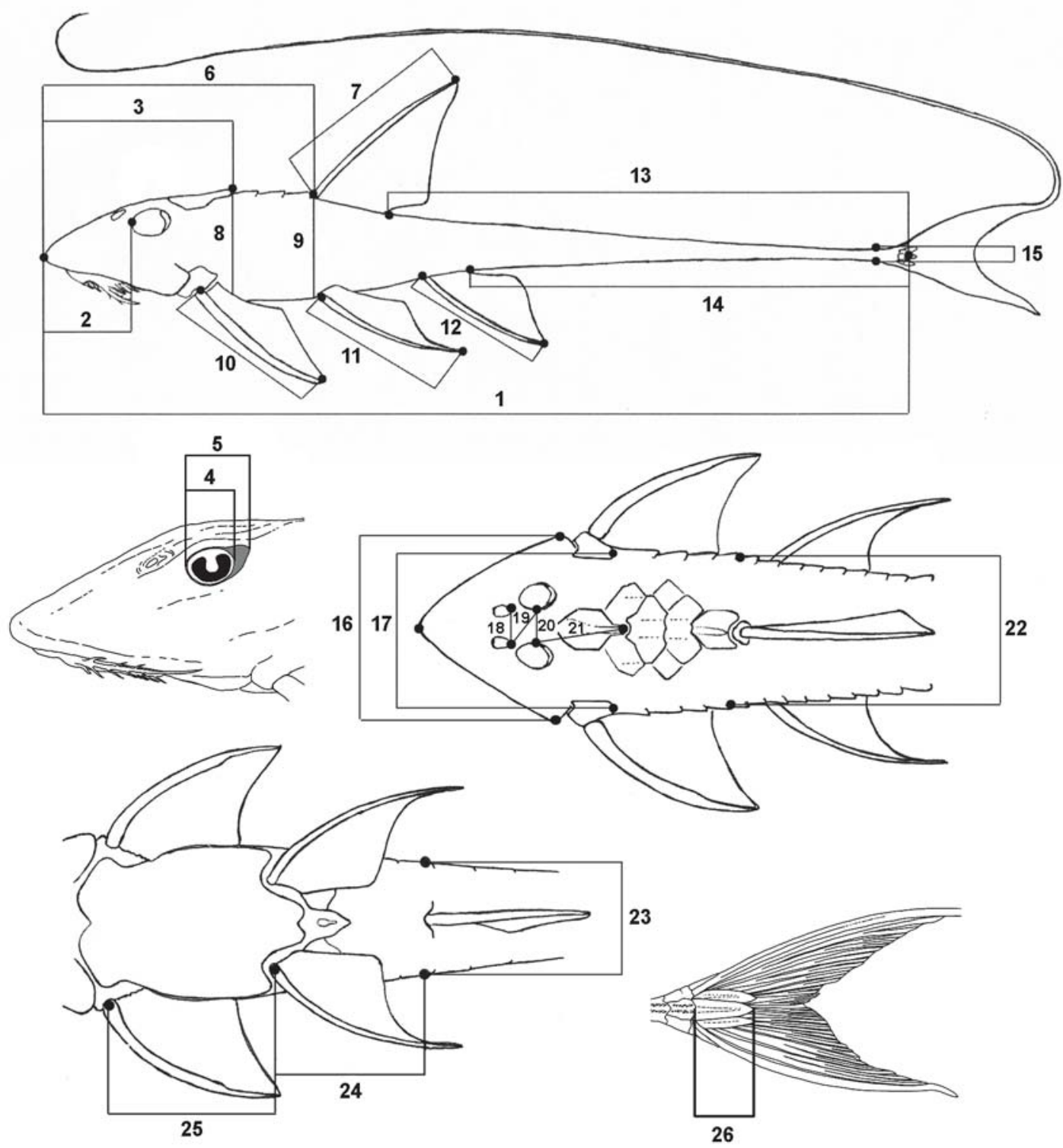

Fig. 1. Diagrammatic representation of measurements used in morphometric analyses, as described in Material and Methods.

toral and pelvic fin origins. Median abdominal plates are polygonal to round in shape, forming a pre-anal shield posteriorly, extending anteriorly to fill the space between the lateral abdominal plates, and often covering the pectoral girdle. Among Loricaria species, median abdominal plates vary in size, spacing, coverage, and the number of rows they form between the lateral abdominal plates. The dorsal flap-like extension of the iris is referred to as the iris operculum, following Douglas et al. (2002).

Specimens were initially grouped into morphotypes based on shared pigmentation patterns, lip morphology, dermal plate development and pattern, and meristic characters. Morphometric variables useful in distinguishing species were identified by comparing measurements expressed as proportions of either SL or HL. This was accomplished through univariate analyses of proportional values using quantile box plots to determine the extent of overlap in ranges between species, followed by Tukey-Kramer HSD tests to identify significant $(P<0.05)$ differences among group means. Meristic data were arranged in frequency distributions and examined for nonoverlapping ranges or modal differences useful in distinguishing species.

\section{Results}

\section{Loricaria spinulifera, new species}

Figs. 2, 3a-b, and 4b

Holotype. INPA 28849 (1, 137.7 mm SL), Brazil, Amazonas, rio Jauaperi (Negro dr.), $8.3 \mathrm{~km}$ upstream from confluence with rio Negro, $9.6 \mathrm{~km}$ upstream from S. Francisco (013'08.4”S, 61²8'34.9”W), 7 Dec 1993, J. P. Friel et al. 


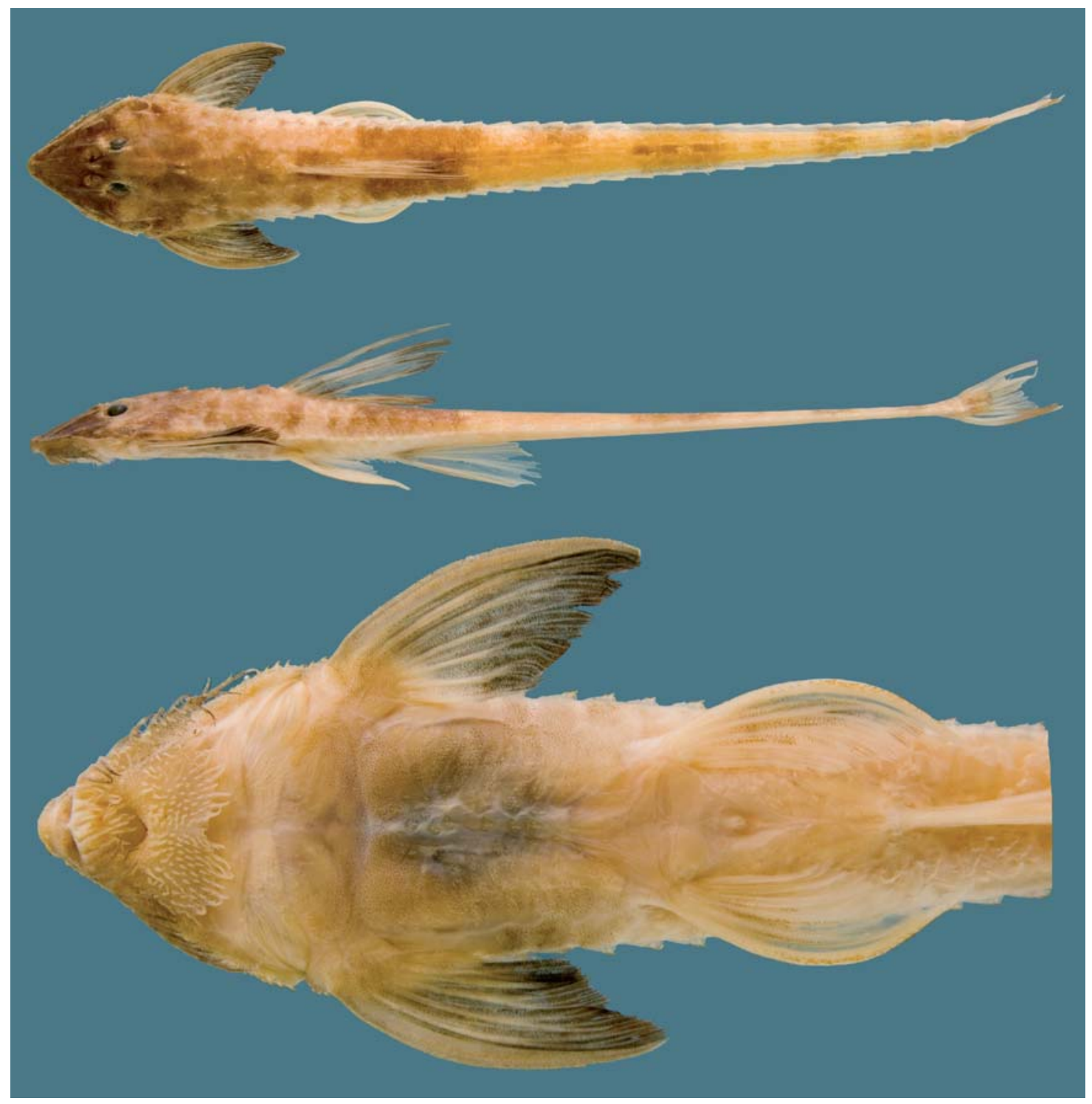

Fig. 2. Loricaria spinulifera, paratype, ANSP 178690 (123.0 mm SL), rio Negro (Amazonas dr.), $11.3 \mathrm{~km}$ downstream from Santa Maria, $18.6 \mathrm{~km}$ upstream from Leprosário, Amazonas, Brazil.

Paratypes (12). Brazil: Amazonas: ANSP 178690 (1, $123.0 \mathrm{~mm}$ $\mathrm{SL}$ ), rio Negro (Amazonas dr.), $11.3 \mathrm{~km}$ downstream from Santa Maria, $18.6 \mathrm{~km}$ upstream from Leprosario $\left(03^{\circ} 01^{\prime} 36.0^{\prime \prime} \mathrm{S}\right.$, 60²4'12.0”W), 12 Dec 1993, J. G. Lundberg et al.; ANSP 178691 $(1,78.6 \mathrm{~mm} \mathrm{SL})$ rio Negro (Amazonas dr.), $10.6 \mathrm{~km}$ downstream from Leprosário, $14.8 \mathrm{~km}$ upstream from Manaus (0306'36.0”S, 60²4'12.0”W), 10 Oct 1994, J. G. Lundberg et al.; INPA 28850 (1, $95.4 \mathrm{~mm} \mathrm{SL}$ ), rio Negro (Amazonas dr.), $12.6 \mathrm{~km}$ downstream from Santa Maria, $16.3 \mathrm{~km}$ upstream from Leprosário (0302’01.8”S, 60²3'23.2”W), 12 Dec 1993, J. G. Lundberg et al.; INPA 28851 (3, 106.0-125.4 mm SL), rio Negro (Amazonas dr.), $10.0 \mathrm{~km}$ downstream from Santa Maria, $18.9 \mathrm{~km}$ upstream from Leprosário (0301'24.5”S, 60²4'19.6”W), 13 Dec 1993, J. G. Lundberg et al.; MZUSP 57447 (1, $60.9 \mathrm{~mm}$ SL), rio Negro (Amazonas dr.), near Santa Maria, (0304'11.0”S, 60¹1'03.0”W), 19 Jul 1996; MZUSP 57636 (3, 43.4-72.2 mm SL), rio Negro (Amazonas dr.), above Tarumã-mirim (0304'04.0”S, 60¹4'58.0”W), 17 Jul 1996. Roraima: ANSP 178687 (1+ 1 c\&s, 116.9-120.6 mm SL), rio Branco (Negro dr.), $13.9 \mathrm{~km}$ upstream from confluence with rio Negro, between Atauba (town upstream) and Caruna (downstream) (01 $17^{\circ} 24.0^{\prime \prime} \mathrm{S}$, 6151'08.0'W), 8 Dec 1993, J. G. Lundberg et al.

Diagnosis. Loricaria spinulifera is distinguished from all congeners by the following unique characters: strongly developed crests on surfaces of head and predorsal plates bearing large thorn-like odontodes (Fig. 3a) vs. weakly developed crests on surfaces of head and predorsal plates without large thorn-like odontodes; a unique arrangement of oral papillae situated behind the premaxillary teeth consisting of approximately 20 papillae, all longer than premaxillary teeth, arranged in a dense cluster (Fig. 3b), vs. approximately 16 short papillae, no longer than premaxillary teeth (Fig. 3d); a unique arrangement of plates on the median abdominal area consisting of small round to diamond-shaped plates varying in size and spacing, with pre-anal shield absent or with few small plates 


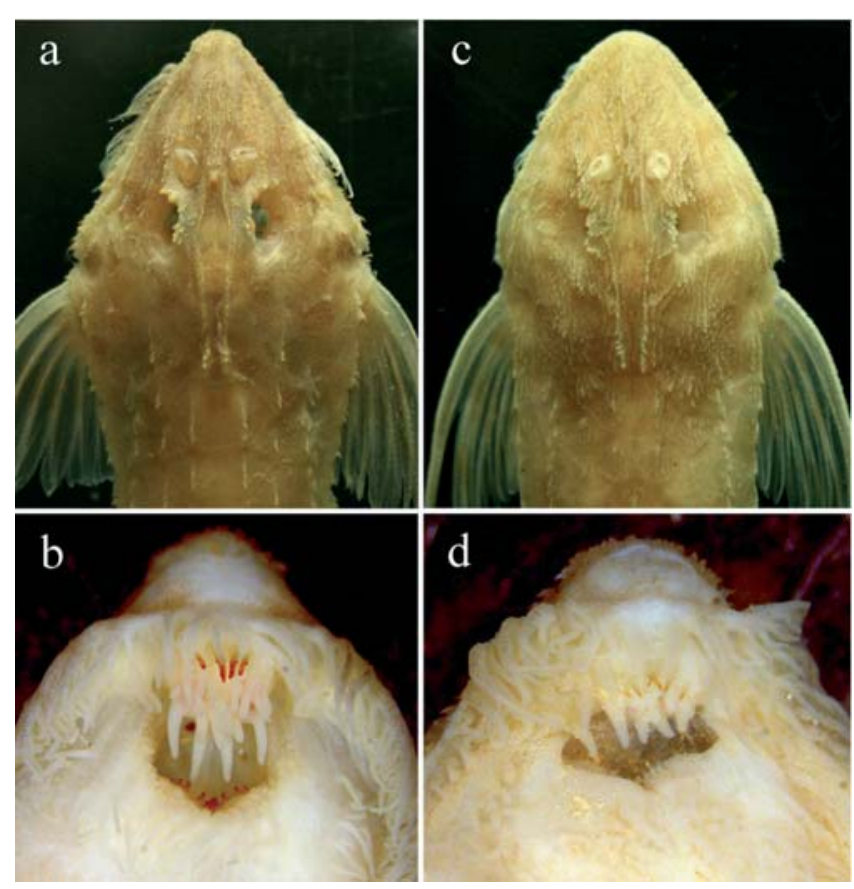

Fig. 3. Odontode ornamentation on the dorsal surface of the head and buccal papillae development in the oral cavity. a-b. L. spinulifera, INPA 28851 (106.0 mm SL); c-d. L. pumila, holotype, INPA 28852 [ex. ANSP 178685] (74.6 mm SL).

distributed along the center and around anterior margin of anus (Fig. 4b); and a unique pigment pattern on the dorsal surface of the head consisting of solid dark brown extending from center of orbits to tip of snout with large irregular spots from center of orbits to middle of dorsal fin.

Description. Standard length of specimens examined 78.6$137.7 \mathrm{~mm}$ SL. Other morphometric data presented in Table 1. Meristic data for selected dermal plate characters in Table 2.

Body elongate and slender, dorsoventrally depressed, widest at cleithrum. Head evenly convex in transverse profile; triangular in frontal profile, lateral margins from snout tip to operculum straight to slightly concave, snout pointed. Dorsal profile of head from snout tip to parieto-supraoccipital tip slightly convex, straight from parieto-supraoccipital tip to dorsal-fin origin. Dorsal profile of body from dorsal-fin origin to caudal peduncle slightly concave. Greatest body depth at dorsal-fin origin, 8.0-9.4\% SL. Eye small, maximum orbital diameter 16.0-19.3\% HL; iris operculum absent. Postorbital notch moderately developed, angular.

Entire body covered with dermal plates except for ventral surface of head anterior to branchiostegals, various portions of median abdominal area, around bases of pelvic fins, and Vshaped area surrounding anus. Dermal plates on dorsum of body from snout tip to dorsal-fin origin with well-developed odontode crests. Large thorn-like odontodes present on lateral margins of head from snout tip to opercle; several large odontodes concentrated on dorsal and ventral margin of snout tip and along anterodorsal margin of orbit. Two promi- nent odontode crests originating at snout tip converge between nares, at single large odontode, becoming divergent on frontals, continuing in parallel to posterior parieto-supraoccipital tip, each terminating in 2-3 large odontodes. Dorsal and dorsolateral plates between pterotic-supracleithrum and dorsal-fin origin each with single crest terminating posteriorly in single large odontode. Lateral surface of exposed cleithrum with conspicuous median keel consisting of 3-5 large odontodes.

Upper lip narrow with numerous marginal fringe barbels, each with multiple branches. Maxillary barbel long, extending to branchiostegals, with numerous secondary barbels, each with multiple tertiary branches. Lower lip well developed with conspicuous median notch; surface covered with numerous elongate filaments; and marginal fringe barbels with multiple branches. Premaxillary teeth 3-4 on each side; each tooth consisting of slender stalk ending in enlarged bilobed crown; outer lobe small, rounded or conical; inner lobe large, rounded or conical. Buccal papillae behind premaxillary teeth elongate and thin, longer than premaxillary teeth, tightly arranged in dense cluster of approximately 20. Dentary teeth 6-9 on each side; less than half the length of premaxillary teeth; structure similar to that of premaxillary teeth except lobes usually shorter, more rounded.

Total plates in lateral series 34-35 (modally 34). Anterior 16-18 lateral plates with two parallel odontode keels widely separated, converging at midline on caudal peduncle; posterior (coalesced) lateral plates 16-18 (modally 17). Post-anal plates 21. Lateral abdominal plates 6-9 (modally 7), sickle shaped and slightly bent at center with odontodes forming inconspicuous keel anterior to pelvic-fin origin. Median abdominal area naked or with small round to diamond-shaped plates varying in number, size, and spacing; thin line of small plates usually present posterior to gill openings; pre-anal shield absent or with few small plates distributed along the center and around anterior margin of anus (Fig. 4b).

Dorsal fin when depressed reaching ninth plate posterior to its origin; distal margin slightly concave when erected. Pectoral fin, when depressed, reaching sixth or seventh lateral plate posterior to cleithrum; distal margin straight to slightly concave when erected. Unbranched pelvic-fin ray (spine) longest, reaching to anterior third of anal-fin length. Anal fin when depressed reaching seventh or eighth plate posterior to its origin; distal margin convex when erected. Distal margin of caudal fin concave, upper unbranched ray produced into long filament (usually damaged or broken) at least two-thirds of standard length.

Color in alcohol. Ground color tan to pale yellow. Solid dark brown covering dorsal surface of head from snout tip to center of orbit; large brown blotches irregularly distributed on dorsal surface of remaining head and trunk. Four or five dark brown transverse bands on dorsal surface from middle of dorsal fin to caudal peduncle usually conspicuous. Dorsal surfaces of upper lip and maxillary barbel with heavy sprin- 
a

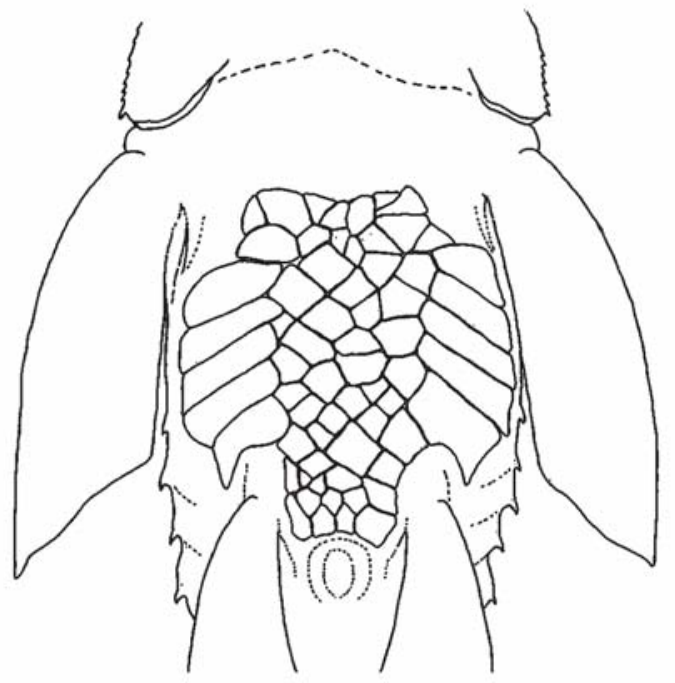

C

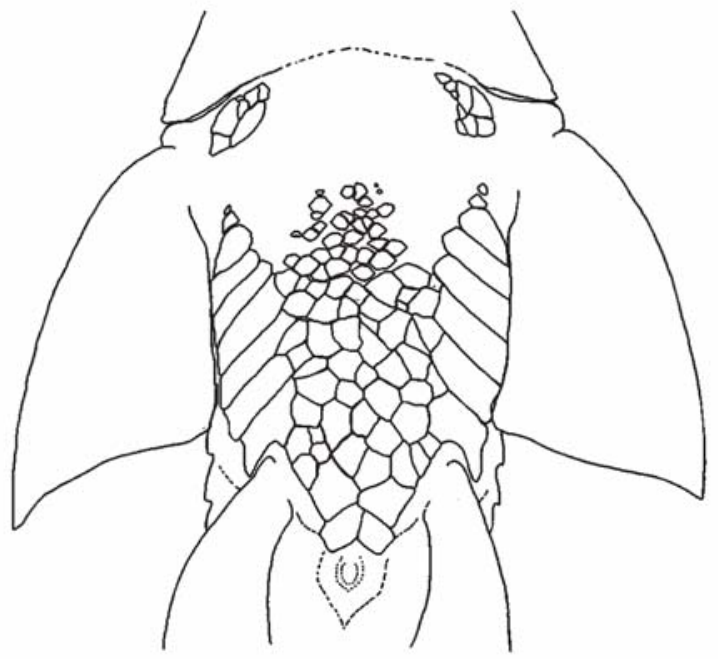

b

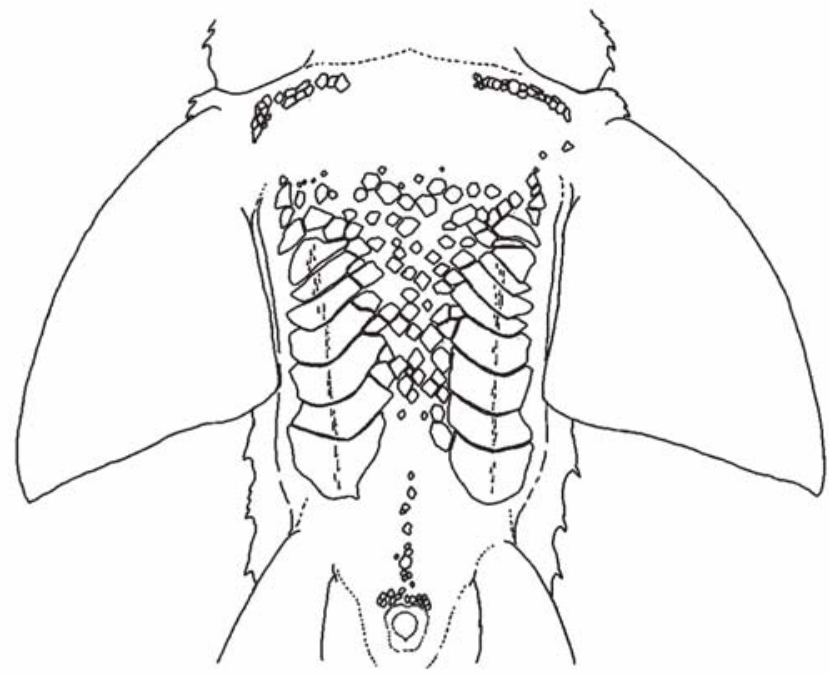

d

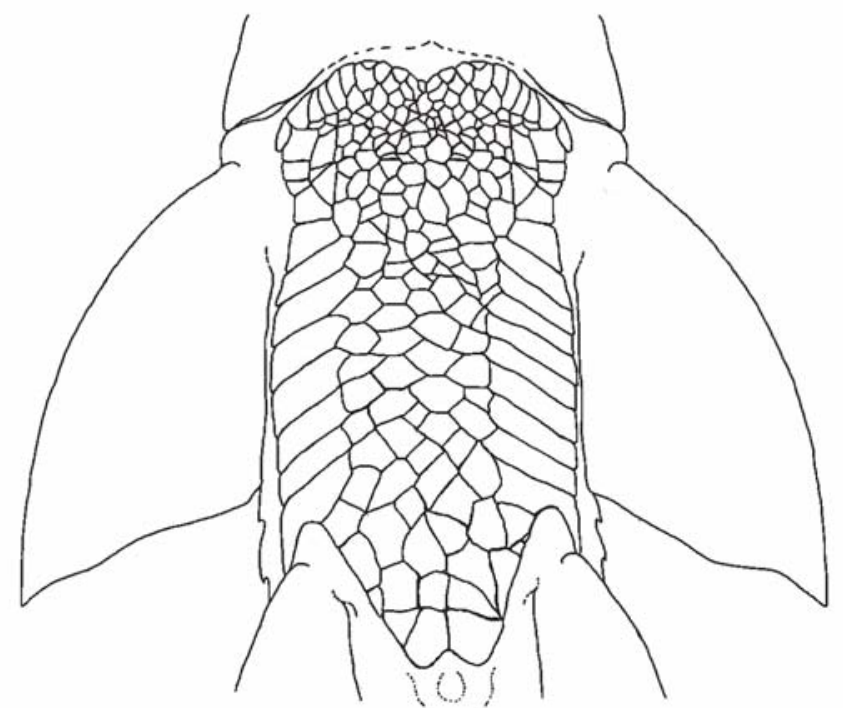

Fig. 4. Variation in abdominal plate development and configuration in Loricaria. a. L. pumila; b. L. spinulifera; c. L. lundbergi; d. L. simillima.

kling of melanophores. Ventral surfaces pale yellow or with light scattering of melanophores between pectoral fin and on lateral abdominal plates. Pectoral and dorsal fins with evenly distributed dark brown melanophores, becoming more intense near distal edge. Pelvic fin opaque, hyaline or with light sprinkling of brown melanophores on interradial membranes. Anal fin hyaline or opaque. Caudal fin opaque, hyaline, or with light brown surrounding edges of basicaudal plate and along distal edge of lower lobe.
Variation. Specimens collected in deep channels have smaller eyes that are more recessed in the orbits (Fig. 3a) than individuals from shallower depths (Fig. 2) and tend to be less boldly pigmented, with dark patterns on the head, body and fins more diffuse or faded. Minimum orbital diameter measurements as proportions of HL were plotted against average capture depths calculated from reported maximum and minimum trawling depths for each collection. Bivariate regression analyses revealed a significant relationship between mini- 


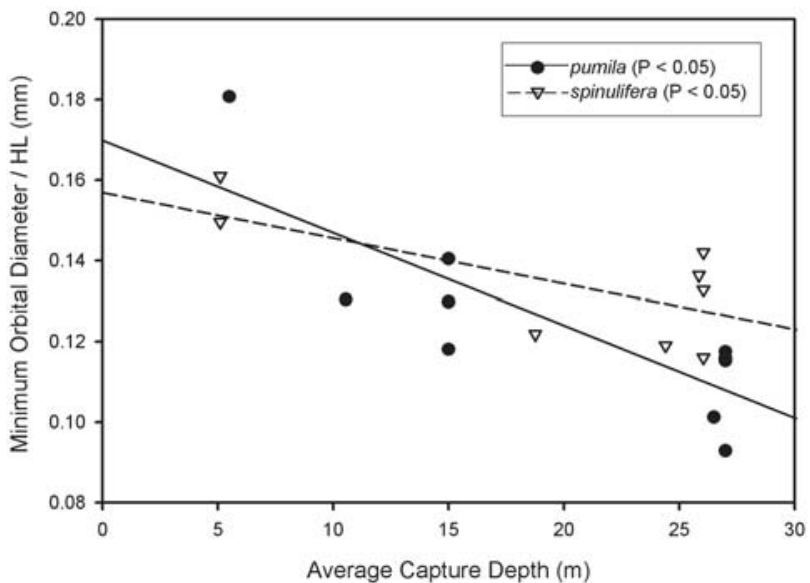

Fig. 5. Relationship between minimum orbital diameter (as \% of HL) and average capture depth for specimens of Loricaria pumila $\left(R^{2}=0.692, P<0.05\right)$ and $L$. spinulifera $\left(R^{2}=0.515, P\right.$ $<0.05)$.

mum orbital diameter and average capture depth for Loricaria spinulifera $\left(R^{2}=0.515, F_{1,6}=6.37, P<0.05\right.$; Fig. 5).

Sexual dimorphism. Two specimens examined(ANSP 178687, 116.9 and $120.6 \mathrm{~mm} \mathrm{SL}$ ) possess traits observed in breeding males of other Loricaria and other putatively derived members of the tribe Loricariini (Isbrücker, 1981; Isbrücker \& Nijssen, 1992). In each of these specimens, filaments on the lower lip are reduced in length, with an increase in number and development of globular papillae on lip surfaces surrounding bases of filaments. Surface area of lower lip enlarged through expansion of membranous connections between lower lip and rictal barbel and at the median cleft. Both the enlarged apical lobe and smaller outer lobe of premaxillary and dentary teeth are much shorter and more broadly rounded (mitten-shaped) than in other specimens. Pectoral spines are slightly thickened from the base to approximately threefourths the length of each spine; thickening is even throughout, rather than the distally expanded or club-like condition reported in certain other species (e.g., L. clavipinna). Odontodes on pelvic- and anal-fin spines are blunt rather than pointed and conical in shape as seen in non-nuptial males and females. Dissection of one specimen (120.6 mm SL) revealed enlarged mature testes, flattened and white in color.

Distribution and ecology. Loricaria spinulifera is known from the rio Negro of Brazil, and from the lower rio Branco downstream to the mouth of the rio Negro, including the lower rio Jauaperi (Fig. 6). This species appears to favor deep channels of large black water rivers. All specimens were collected in bottom trawls at depths ranging from 1.5 to $28 \mathrm{~m}$ and at distances of 10 to $750 \mathrm{~m}$ from the shoreline (J. G. Lundberg et al., unpubl. data). Some specimens were reportedly collected over substrates of sand, mud, and organic debris. Stomach contents of a single dissected specimen (ANSP 178687, 120.6 $\mathrm{mm} \mathrm{SL}$ ) collected in depths of 1.5 to $8.7 \mathrm{~m}$ contained sclerotized body parts of aquatic insect larvae of the orders Trichoptera and Diptera, as well as organic detritus and sand.

Table 1. Proportional measurements for Loricaria spinulifera $(\mathrm{n}=13)$, L. lundbergi $(\mathrm{n}=7)$, and L. pumila $(\mathrm{n}=11)$. $\mathrm{H}=$ holotype.

\begin{tabular}{|c|c|c|c|c|c|c|c|c|c|}
\hline \multirow[b]{2}{*}{ Measurement } & \multicolumn{3}{|c|}{ Loricaria spinulifera } & \multicolumn{3}{|c|}{ Loricaria lundbergi } & \multicolumn{3}{|c|}{ Loricaria pumila } \\
\hline & $\mathrm{H}$ & Mean & Range & $\mathrm{H}$ & Mean & Range & $\mathrm{H}$ & Mean & Range \\
\hline $\mathrm{SL}(\mathrm{mm})$ & 137.7 & 113.7 & $78.6-137.7$ & 103.6 & 93.1 & $76.6-138.1$ & 74.6 & 70.4 & $56.1-81.0$ \\
\hline \multicolumn{10}{|c|}{ Percents of standard length } \\
\hline Head length & 20.3 & 19.8 & $19.1-20.6$ & 22.2 & 22.6 & $21.4-23.7$ & 22.8 & 22.4 & $21.4-22.8$ \\
\hline Predorsal length & 29.5 & 28.9 & $27.7-29.7$ & 29.7 & 30.1 & $29.6-30.7$ & 32.1 & 30.5 & $28.8-32.1$ \\
\hline Dorsal spine length & - & 20.3 & $18.9-21.8$ & 19.2 & 19.3 & $17.4-21.7$ & 21.4 & 19.5 & $17.6-21.4$ \\
\hline Body depth & 9.1 & 8.6 & $8.0-9.4$ & 9.1 & 8.8 & $8.1-9.7$ & 10.5 & 9.2 & $8.2-10.7$ \\
\hline Pectoral spine length & 16.5 & 16.0 & $15.4-16.5$ & 16.1 & 17.9 & $16.1-19.3$ & 18.3 & 17.0 & $15.5-18.6$ \\
\hline Pelvic spine length & 16.8 & 14.5 & $13.5-16.8$ & 15.7 & 17.3 & $15.7-17.9$ & 20.5 & 18.4 & $15.4-20.5$ \\
\hline Anal spine length & 15.1 & 15.4 & $14.1-16.6$ & 14.4 & 15.6 & $14.4-17.4$ & 18.0 & 16.4 & $15.3-18.3$ \\
\hline Post-dorsal length & 61.7 & 63.3 & $61.7-64.2$ & 62.2 & 62.4 & $62.0-63.0$ & 60.0 & 60.8 & $59.6-63.8$ \\
\hline Post-anal length & 54.9 & 55.9 & $54.9-57.5$ & 54.4 & 54.0 & $51.6-55.1$ & 53.4 & 53.9 & $52.7-55.5$ \\
\hline Head width & 15.9 & 16.1 & $15.2-16.7$ & 17.6 & 18.0 & $17.6-18.4$ & 18.2 & 17.1 & $16.4-18.2$ \\
\hline Body width at post-cleithral tip & 12.4 & 12.1 & $11.7-12.8$ & 12.1 & 12.3 & $11.9-12.6$ & 12.9 & 12.4 & $12.0-13.1$ \\
\hline Body width at dorsal spine origin & 12.6 & 12.3 & $11.6-13.1$ & 12.7 & 12.8 & $12.0-14.7$ & 14.1 & 12.7 & $11.6-14.1$ \\
\hline Body width at anal spine origin & 10.5 & 10.4 & $9.7-11.6$ & 9.8 & 10.5 & $9.8-12.4$ & 11.7 & 10.3 & $9.1-11.9$ \\
\hline Abdominal length & 11.7 & 11.7 & $10.8-12.4$ & 12.2 & 12.0 & $11.0-13.0$ & 12.9 & 12.9 & $11.9-14.7$ \\
\hline Thoracic length & 16.1 & 15.6 & $14.9-16.1$ & 15.8 & 15.5 & $13.9-16.7$ & 15.3 & 14.0 & $12.8-15.3$ \\
\hline \multicolumn{10}{|c|}{ Percents of head length } \\
\hline Caudal peduncle least depth & 5.5 & 5.6 & $5.1-5.8$ & 4.5 & 4.7 & $4.3-5.6$ & 5.2 & 5.3 & $5.0-5.6$ \\
\hline Head depth & 39.4 & 40.0 & $37.3-41.8$ & 38.8 & 37.2 & $34.0-39.3$ & 45.0 & 41.9 & $38.0-47.5$ \\
\hline Snout length & 51.3 & 51.5 & $50.1-52.3$ & 54.3 & 52.9 & $51.1-54.5$ & 54.1 & 53.0 & $51.3-56.0$ \\
\hline Minimum orbital diameter & 14.5 & 13.6 & $11.6-16.1$ & 16.4 & 15.6 & $15.1-16.4$ & 10.1 & 12.4 & $9.3-18.1$ \\
\hline Maximum orbital diameter & 17.2 & 17.9 & $16.0-19.3$ & 18.2 & 18.6 & $17.8-21.2$ & 16.2 & 16.9 & $15.4-20.4$ \\
\hline Internares width at posterior bony nostrils & 12.4 & 12.8 & $11.9-14.0$ & 11.7 & 11.4 & $10.9-11.8$ & 12.8 & 12.0 & $11.1-13.1$ \\
\hline Nares to orbit at frontal-sphenotic juncture & 20.4 & 22.2 & $20.4-23.8$ & 20.2 & 20.3 & $18.8-21.6$ & 24.5 & 22.6 & $20.6-24.5$ \\
\hline Interorbital width at frontal-sphenotic juncture & 18.9 & 21.2 & $18.9-23.7$ & 21.2 & 20.7 & $19.6-21.5$ & 24.4 & 23.3 & $21.0-27.2$ \\
\hline Orbit at frontal sphenotic juncture to SOC tip & 38.4 & 40.5 & $38.4-43.4$ & 38.7 & 38.9 & $37.7-40.6$ & 40.4 & 40.6 & $39.3-42.9$ \\
\hline Basicaudal plate length & 12.2 & 11.4 & $10.3-12.2$ & 10.4 & 10.1 & $9.0-11.9$ & 10.3 & 9.7 & $8.2-11.2$ \\
\hline
\end{tabular}




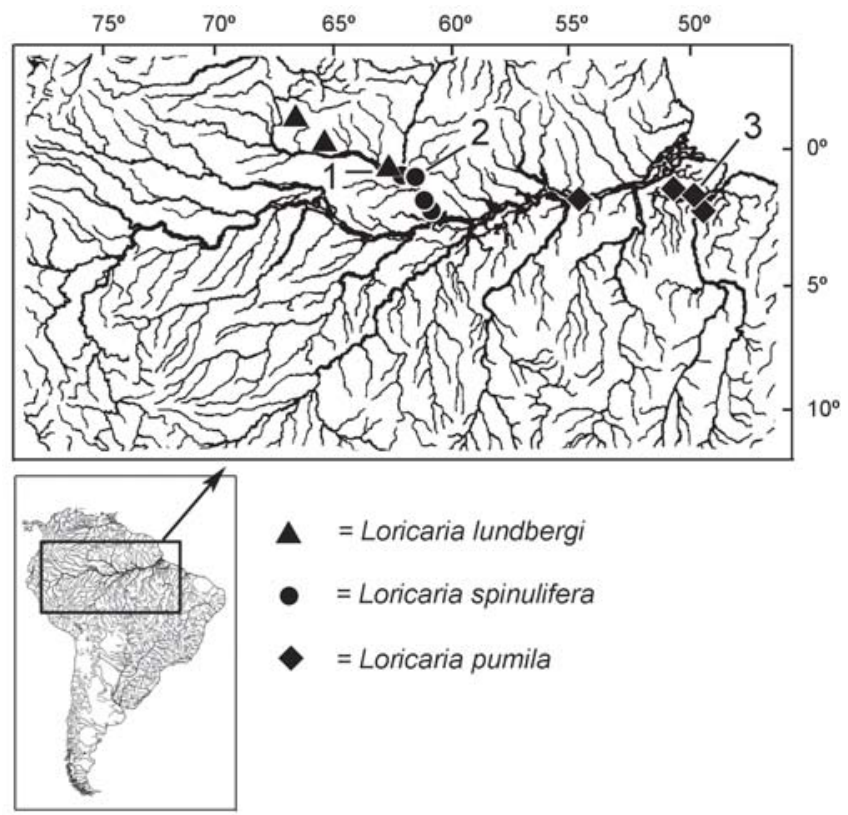

Fig. 6. Geographic distributions of Loricaria lundbergi (type locality $=1)$, L. spinulifera $($ type locality $=2)$, and L. pumila (type locality $=3$ ) based on material examined.

Etymology. From the Latin word spinula meaning "a small thorn, spine" and the adjective suffix fero meaning "to bear, carry, bring". The specific name implies "bearing little thorns", in reference to the conspicuous thorn-like odontodes on the dorsal and lateral surfaces of the head.

\section{Loricaria pumila, new species}

Figs. 7a-b, 3c-d, and 4a

Holotype. INPA 28852 [ex. ANSP 178685] (1, 74.6 mm SL), Brazil, Pará, rio Pará (Amazonas dr.), $15.5 \mathrm{~km}$ downstream of Curralinho, $9.4 \mathrm{~km}$ upstream from Paquetá $\left(01^{\circ} 48^{\prime} 03.0^{\prime \prime}\right.$, 49³9'53.0”W), 18 Nov 1994, A. M. Zanata et al.

Paratypes (10). Brazil: Pará: ANSP 178684 (2+ 1 c\&s, 123.0 mm $\mathrm{SL}$ ), rio Amazonas, $9.7 \mathrm{~km}$ downstream of Vila Canaã, $10.2 \mathrm{~km}$ upstream from Porto S. José (01 $\left.{ }^{\circ} 33^{\prime} 22.0^{\prime \prime} \mathrm{S}, 50^{\circ} 44^{\prime} 05.0^{\prime \prime} \mathrm{W}\right), 16$ Nov 1994, A. M. Zanata et al.; ANSP 178689 (1, $81.0 \mathrm{~mm} \mathrm{SL})$, rio Tocantins (Amazonas dr.), $11.3 \mathrm{~km}$ downsteam of Curucambaba, $24.8 \mathrm{~km}$ upstream from Naiuata $\left(02^{\circ} 02^{\prime} 22.0^{\prime \prime} \mathrm{S}, 49^{\circ} 17^{\prime} 26.0^{\prime \prime} \mathrm{W}\right), 20$ Nov 1994, A. M. Zanata et al.; INPA 28853 [ex. ANSP 178686] (3, 59.6-78.3 mm SL) rio Pará (Amazonas dr.), above rio Tocantins, $83.3 \mathrm{~km}$ upstream from Abaetetuba, $9.1 \mathrm{~km}$ downstream from Boa Vista (01 ${ }^{\circ} 45^{\prime} 22.0^{\prime \prime}$ 'S, 49²8'48.0"W), 18 Nov 1994, A.M. Zanata, et al.; MZUSP 100310 [ex. ANSP 178686] (2, 56.9-68.8 mm SL), same data as INPA 28853; MZUSP 100311 [ex. ANSP 178693] (1, $56.1 \mathrm{~mm} \mathrm{SL}$ ), rio Amazonas, $34.3 \mathrm{~km}$ downstream of Cabeça de Onça, $2.8 \mathrm{~km}$ upstream of Santarem ( $\left.02^{\circ} 23^{\prime} 59.9^{\prime \prime S}, 54^{\circ} 41^{\prime} 56.7^{\prime \prime} \mathrm{W}\right)$, 1 Nov 1994, O. Oyakawa et al.

Diagnosis. Loricaria pumila is distinguished from all species of Loricaria except $L$. nickeriensis by attaining a small adult size, reaching sexual maturity at less than $80 \mathrm{~mm}$ SL. Loricaria pumila can be distinguished from Loricaria nickeriensis and Amazon basin Loricaria by the following combination of characters: prominent crests on surfaces of head and predorsal plates with numerous well developed odontodes arranged in conspicuous linear rows (Fig. 3c), vs. weakly developed crests on head and predorsal plates with odontodes not arranged in conspicuous linear rows; anterior abdominal area covering pectoral girdle naked, with occasional small isolated plates at bases of pectoral fins, pre-anal shield and space between lateral abdominal plates with large polygonal plates (Fig. 4a), vs. anterior abdominal area and pre-anal shield covered with tightly arranged plates (Fig. 4d); 31-32 (modally 31 ) vs. 32-36 (modally 33-34, rarely 32 ) total lateral plates; and 18-19 (modally 18) vs. 19-22 (modally 20-21) post-anal plates (Table 2).

Description. A diminutive species, standard length of specimens examined 56.1-81.0 $\mathrm{mm}$ SL. Other morphometric data presented in Table 1. Meristic data for selected dermal plate characters in Table 2.

Body moderately elongate and slender, dorsoventrally depressed, widest at posterolateral corner of head ventral to opercle. Head in transverse profile slightly concave between lateral margins and ventral rim of orbit, straight on top of head between orbits; bluntly triangular in frontal profile, lateral margins from snout tip to operculum slightly convex, snout slightly rounded. Dorsal profile of head from snout tip to parieto-supraoccipital tip slightly convex, straight from parieto-supraoccipital tip to dorsal-fin origin. Dorsal profile of body from dorsal-fin origin to caudal peduncle slightly concave. Greatest body depth at posterior tip of parieto-supraoccipital, 8.2-10.7\% SL. Eye generally small, but variable (see Variation, below), maximum orbital diameter 15.4-20.4\% HL; iris operculum slightly developed or absent. Postorbital notch inconspicuous, rounded.

Entire body covered with dermal plates except for ventral surface of head anterior to branchiostegals, anterior median abdominal area between pectoral fins, around bases of pelvic fins, and V-shaped area surrounding anus. Dermal plates on dorsum of body from snout tip to dorsal-fin origin with prominent odontode crests and numerous well developed, sharply pointed odontodes arranged in conspicuous rows. Odontodes strongly developed on lateral margins of head from snout tip to opercle and along anterodorsal margin of orbit. Two prominent odontode crests originating at snout tip converging between nares, becoming divergent on frontals, continuing in parallel to posterior parieto-supraoccipital tip. Dorsal and dorsolateral plates between pterotic-supracleithrum and dorsal-fin origin each with a single prominent median crest and several smaller odontode rows. Lateral surface of exposed cleithrum with inconspicuous median keel of odontodes. Dorsal and lateral plates from dorsal-fin origin to caudal peduncle bearing well developed odontodes forming conspicuous linear rows. 

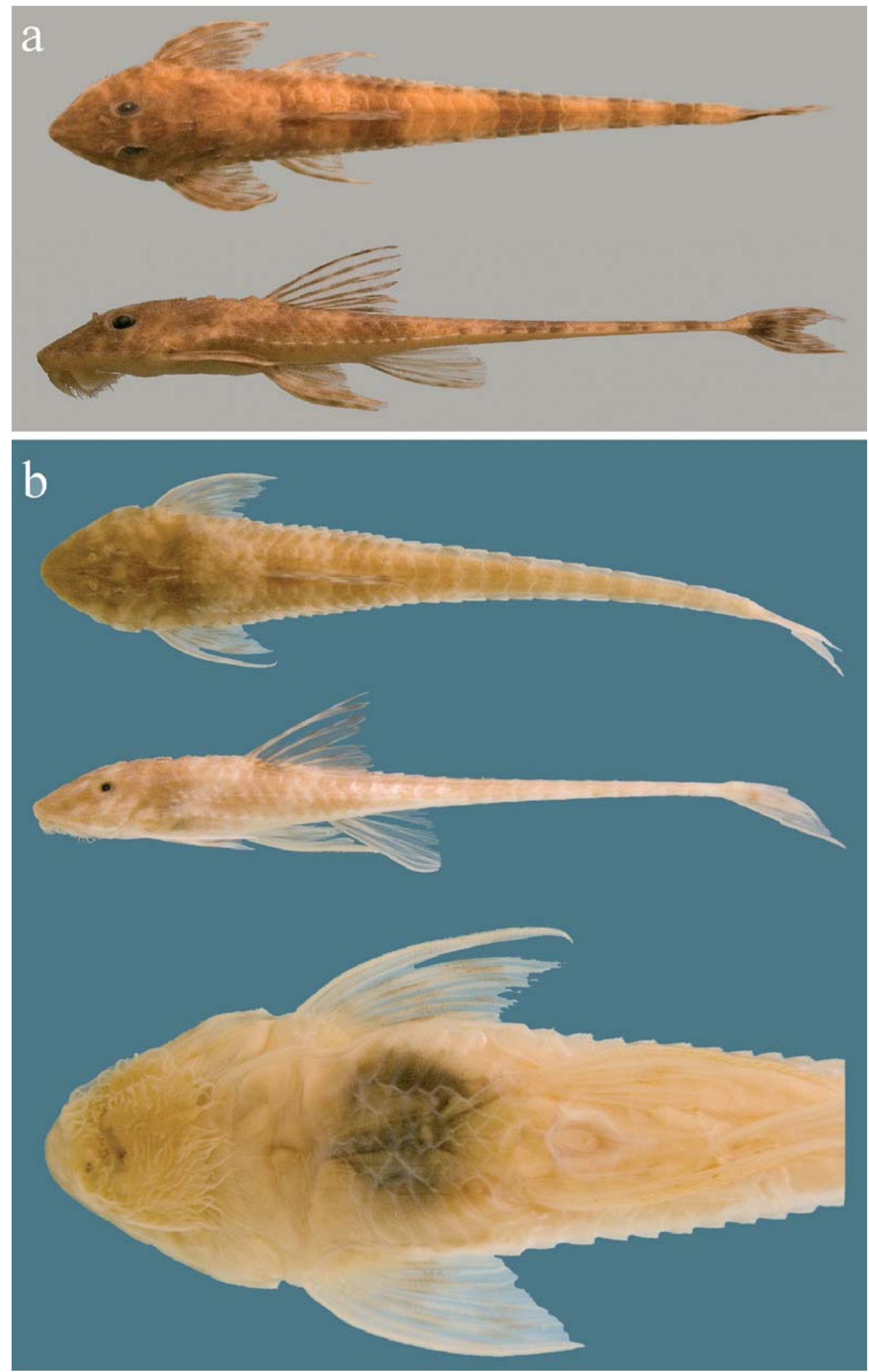

Fig. 7. Loricaria pumila. a. paratype, ANSP 178689 (81.0 mm SL), rio Tocantins (Amazonas dr.), $11.3 \mathrm{~km}$ downsteam of Curucambaba, $24.8 \mathrm{~km}$ upstream from Naiuata, Pará, Brazil; b. holotype, INPA 28852 [ex. ANSP 178685] (74.6 mm SL), rio Pará (Amazonas dr.), 15.5 km downstream of Curralinho, 9.4 km upstream from Paquetá, Pará, Brazil. 
Table 2. Frequency distribution of plate counts for selected Amazon basin Loricaria species.

\begin{tabular}{lcccccccc}
\hline Total lateral plates & $n$ & 31 & 32 & 33 & 34 & 35 & 36 & \\
\hline L. cataphracta & 41 & & 1 & 16 & 21 & 3 & & \\
L. clavipinna & 28 & & & 2 & 22 & 4 & & \\
L. simillima & 118 & & 2 & 22 & 62 & 27 & 5 & \\
L. spinulifera & 13 & & & & 10 & 3 & & \\
L. lundbergi & 7 & & & 6 & 1 & & & \\
L. pumila & 11 & 8 & 3 & & & & & \\
\hline Fused lateral plates & $n$ & 12 & 13 & 14 & 15 & 16 & 17 & 18 \\
\hline L. cataphracta & 41 & & 1 & 6 & 19 & 13 & 2 & \\
L. clavipinna & 28 & & & & 11 & 16 & 1 \\
L. simillima & 118 & 7 & 15 & 58 & 32 & 5 & 1 & \\
L. spinulifera & 13 & & & & & 3 & 6 & 4 \\
L. lundbergi & 7 & & & & 5 & 1 & 1 & \\
L. pumila & 11 & & 1 & 6 & 3 & 1 & & \\
\hline Post-anal plates & $n$ & 18 & 19 & 20 & 21 & 22 & & \\
\hline L. cataphracta & 41 & & 9 & 19 & 13 & & & \\
L. clavipinna & 28 & & 2 & 18 & 7 & 1 & & \\
L. simillima & 118 & & 18 & 62 & 33 & 5 & & \\
L. spinulifera & 13 & & & & 13 & & & \\
L. lundbergi & 7 & & 1 & 5 & 1 & & & \\
L. pumila & 11 & 8 & 3 & & & & \\
\hline Lateral abdominal plates & $n$ & 5 & 6 & 7 & 8 & 9 & 10 & \\
\hline L. cataphracta & 41 & & 1 & 6 & 22 & 7 & 5 \\
L. clavipinna & 28 & & & 5 & 6 & 10 & 7 \\
L. simillima & 117 & & 2 & 19 & 52 & 39 & 5 \\
L. spinulifera & 13 & & 1 & 8 & 3 & 1 & & \\
L. lundbergi & 7 & & 1 & 5 & 1 & & & \\
L. pumila & & 2 & 7 & & & & \\
\hline & & & & & &
\end{tabular}

Upper lip narrow with numerous marginal fringe barbels, each simple, bifid, or trifid. Maxillary barbel short, not extending beyond marginal fringe barbels on lower lip, bearing simple or bifid secondary barbels. Lower lip well developed with shallow median notch; surface covered with numerous elongate filaments; and marginal fringe barbels simple. Premaxillary teeth 3-4 on each side; each tooth consisting of slender stalk ending in enlarged bilobed crown; outer lobe small, rounded or conical; inner lobe large, rounded or conical. Buccal papillae behind premaxillary teeth short, not longer than premaxillary teeth, arranged in cluster of approximately 16 . Dentary teeth 5-8 on each side; less than half length of premaxillary teeth; structure similar to that of premaxillary teeth except lobes usually shorter, more rounded.

Total plates in lateral series 31-32 (modally 31 ). Anterior 16-18 lateral plates with two parallel odontode keels widely separated, converging at midline on caudal peduncle; posterior (coalesced) lateral plates 13-16 (modally 14) . Post-anal plates 18-19 (modally 18). Lateral abdominal plates 5-7 (modally 7), rectangular and elongate. Median abdominal area with large triangular to diamond shaped plates between lateral abdominal plates; area covering pectoral girdle naked, with occasional small isolated plates at bases of pectoral fins; preanal shield well developed (Fig. 4a).

Dorsal fin when depressed reaching seventh or eighth plate posterior to its origin; distal margin straight to slightly concave when erected. Pectoral fin when depressed reaching seventh lateral plate posterior to cleithrum; distal margin straight to slightly concave when erected. Unbranched pel- vic-fin ray (spine) longest, reaching to anterior half of analfin length. Anal fin when depressed reaching seventh plate posterior to its origin; distal margin convex when erected. Distal margin of caudal fin concave, upper unbranched ray produced into long filament (usually damaged or broken) at least two-thirds of standard length.

Color in alcohol. Ground color tan to pale yellow. Diffuse brown blotches irregularly distributed on dorsal surface of head and trunk; faint brown transverse bands on dorsal surface from middle of dorsal fin to caudal peduncle present on most specimens. Dorsal surfaces of upper lip lightly sprinkled with melanophores. Ventral surfaces pale yellow or cream. Pectoral and dorsal fins with elongate brown spots on rays with spaced concentrations of melanophores on interradial membranes. Pelvic fin opaque, hyaline or with faint melanophores arranged in elongate brown spots or irregularly distributed on rays and interradial membranes. Anal fin hyaline or opaque. Caudal fin with elongate brown spots forming vertical bands throughout, faint or inconspicuous on most specimens; light brown melanophores concentrated around edges of basicaudal plate.

Variation. A single specimen (ANSP 178689) collected from the lower rio Tocantins (Fig. 7a) has a larger eye and maximum orbital diameter $(20.4 \% \mathrm{HL})$ than remaining specimens $(\mathrm{n}=10$, maximum orbital diameter 15.4-17.7\% HL) from the lower Amazon. This same specimen also has a slightly developed iris operculum (absent in Amazon specimens) and conspicuous pigment pattern consisting of brown blotches on the head and fins with five dark saddles on the dorsum of the body (patterns in Amazon specimens similar, but diffuse). This individual is identified as Loricaria pumila on the basis of odontode development on head and predorsal plates, abdominal plate pattern and plate counts, all of which are consistent with L. pumila from the deeper Amazon River habitats. Futhermore, this specimen is an adult male exhibiting external sexually dimorphic characters (see Sexual Dimorphism, below). Eye size was observed to be variable among specimens collected at different depths in the lower Amazon, from small and deeply recessed in to the orbit and not visible from above (Figs. $7 b$ and 3c) to distinctly larger and clearly visible from above (see Discussion, below). Bivariate regression analyses revealed a significant relationship between minimum orbital diameter and capture depth based on these specimens $\left(R^{2}=0.692, F_{1,8}=17.96, P<0.05\right.$; Fig. 5$)$.

Sexual dimorphism. Two specimens (INPA 28853, $78.3 \mathrm{~mm} \mathrm{SL}$ and ANSP 178689, $81.0 \mathrm{~mm} \mathrm{SL}$ ) possess sexually dimorphic traits similar to those observed in nuptial male Loricaria spinulifera.

Distribution and ecology. Loricaria pumila is known from the rio Amazonas near the mouth of rio Tapajós and rio Pará adjacent to and including lower rio Tocantins (Fig. 6). All specimens were collected in bottom trawls at depths ranging 
from 3 to $29 \mathrm{~m}$ and at distances of 15 to $1500 \mathrm{~m}$ from the shoreline (J. G. Lundberg et al., unpubl. data). Some specimens were reportedly collected over silt and organic detritus. Ten specimens examined were collected in white waters of the Amazon system; a single specimen (ANSP 178689, 81.0 $\mathrm{mm} \mathrm{SL}$ ) was collected in clear waters of the lower rio Tocantins, at relatively shallow (3 to $8 \mathrm{~m}$ ) depths over a substrate composed of organic detritus. Stomach contents of a single dissected specimen (ANSP 178684, 73.1 mm SL) collected at a depth between 13 to $17 \mathrm{~m}$ contained an entire aquatic insect larva (order Coleoptera), sclerotized body parts of unidentified insects, organic detritus and sand.
Etymology. From the Latin word pumilus meaning "dwarf”, in reference to the small adult size of this species, particularly among Loricaria.

\section{Loricaria lundbergi, new species}

Figs. 8 and $4 \mathrm{c}$

Holotype. INPA 28854 [ex. ANSP 178694] (1, 103.6 mm SL), Brazil, Amazonas, rio Negro (Amazonas dr.), $4.3 \mathrm{~km}$ downstream of Carvoeiro, $37.0 \mathrm{~km}$ upstream of Moura (01 20 '26.4”S, 6155'19.0”W), 9 Dec 1993, J. G. Lundberg et al.

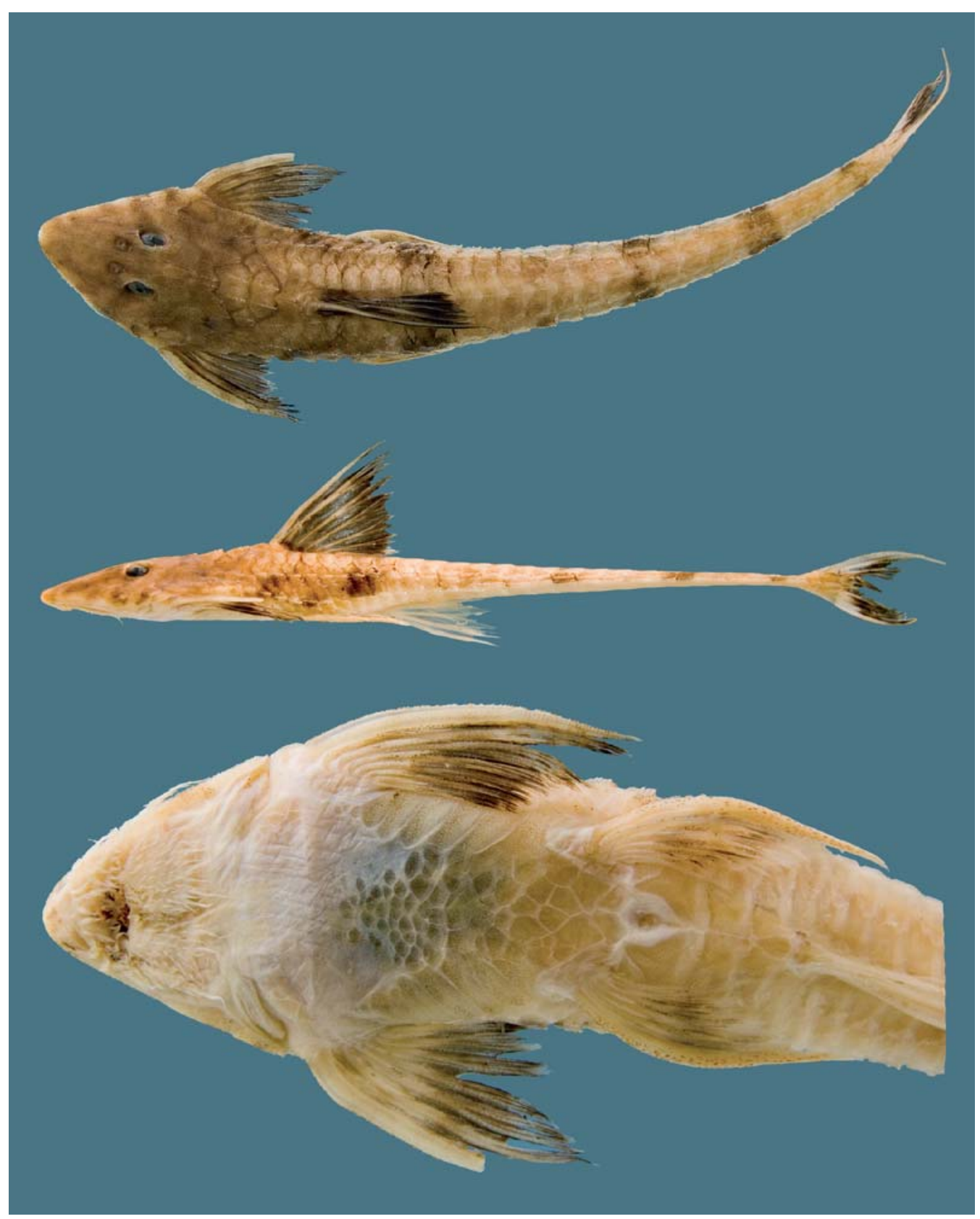

Fig. 8. Loricaria lundbergi, paratype, AMNH 74474 (138.1 mm SL) rio Mawarinuma (Baria-Negro dr.), at Neblina base camp, Amazonas, Venezuela. 
Paratypes (6). Brazil: Amazonas: ANSP 178694 (1 c\&s, 76.8 mm SL), same data as holotype; INPA 28855 [ex. ANSP 178694] (2, 76.6-80.4 mm SL) same data as holotype; ANSP 187412 (2, 84.2$92.4 \mathrm{~mm} \mathrm{SL}$ ), rio Negro (Amazonas dr.), $13.0 \mathrm{~km}$ downstream from Carvoeiro, $38.9 \mathrm{~km}$ upstream from Moura (0120'49.2"S, 61 54 '56.6"W), 9 Dec 1993, J. P. Friel et al. Venezuela: Território Federal Amazonas, Dept. Rio Negro: AMNH 74474 (1, $138.1 \mathrm{~mm}$ $\mathrm{SL}$ ) rio Mawarinuma (Baria-Negro dr.), at Neblina base camp ( $\left.0^{\circ} 55^{\prime} \mathrm{N}, 66^{\circ} 10^{\prime} \mathrm{W}\right), 6$ to 13 Feb 1984, C. J. Ferraris, G. J. Nelson, R. Royero.

Diagnosis. Loricaria lundbergi exhibits the generalized morphology shared with other members of the L cataphracta group, particularly L. cataphracta, L. clavipinna, L. lata, L. parnahybae, L. simillima, and L. tucumanensis. With the exception of L. parnahybae, L. lundbergi is distinguished from these and other congeners by having abdominal plate development confined to the pre-anal shield and posterior median abdominal area, pectoral girdle mostly naked, and with isolated clusters of plates near bases of pectoral fins posterior to gill openings often present in adults (Fig. 4c), vs. abdominal plates typically well developed and tightly arranged across the entire median abdominal area, including the pectoral girdle (Fig. 4d). Loricaria lundbergi differs from L. parnahybae, a species restricted to the rio Parnaíba drainage in northeastern Brazil, by having a broader head (17.6-18.4\% SL vs. 13.7$15.8 \%$ SL; Fig. 9), smaller basicaudal plate (9.0-11.9\% vs. $12.9-$ 15.4\% HL; Fig. 10), body marked with conspicuous dark saddles and fins with solid dark pigment (Fig. 8) vs. body faintly marked with dark saddles and fins with small spots. Loricaria lundbergi is further distinguished from L. simillima, a similar and potentially sympatric species, by having a smaller basicaudal plate (9.0-11.9\% vs. 11.7-23.6\% HL; Fig. 11).

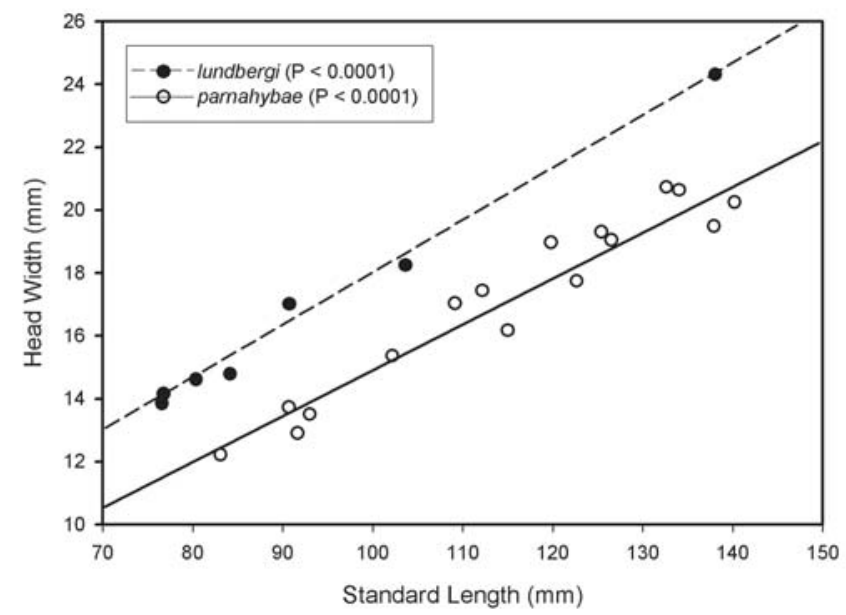

Fig. 9. Bivariate scatterplot and linear regression lines showing relationship between head width and standard length in Loricaria lundbergi $\left(R^{2}=0.991, P<0.0001\right)$ and $L$. parnahybae $\left(R^{2}=0.939, P<0.0001\right)$.
Description. Standard length of specimens examined 76.6$138.1 \mathrm{~mm}$ SL. Other morphometric data presented in Table 1. Meristic data for selected dermal plate characters in Table 2.

Body elongate and slender, dorsoventrally depressed, widest at cleithrum. Head in transverse profile slightly concave between lateral margins and ventral rim of orbit, straight on top of head between orbits; bluntly triangular in frontal profile, lateral margins from snout tip to operculum slightly convex, snout slightly rounded. Dorsal profile of head from snout tip to parieto-supraoccipital tip convex, from parietosupraoccipital tip to dorsal-fin origin slightly concave. Dorsal profile of body from dorsal-fin origin to caudal peduncle slightly concave. Greatest body depth at dorsal-fin origin,

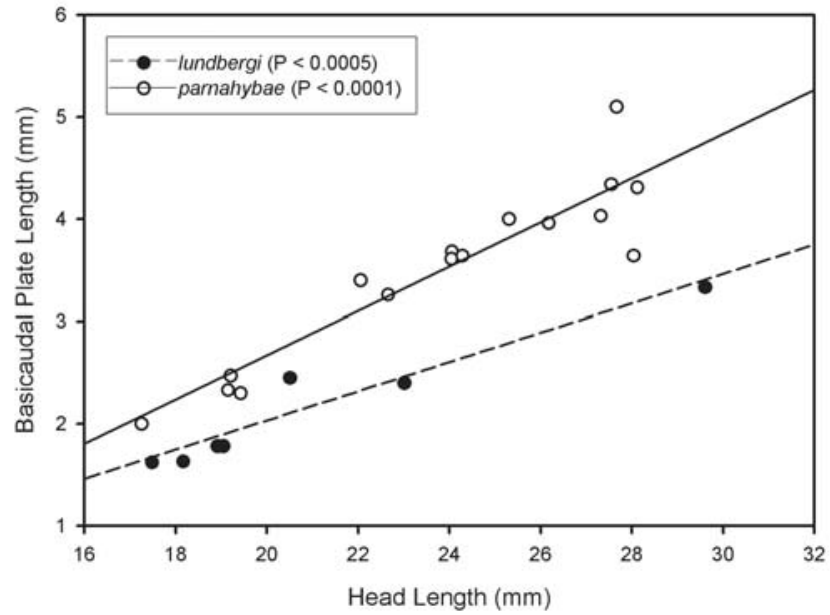

Fig. 10. Bivariate scatterplot and linear regression lines showing relationship between basicaudal plate length and head length in Loricaria lundbergi $\left(R^{2}=0.929, P<0.0005\right)$ and $L$. parnahybae $\left(R^{2}=0.865, P<0.0001\right)$.

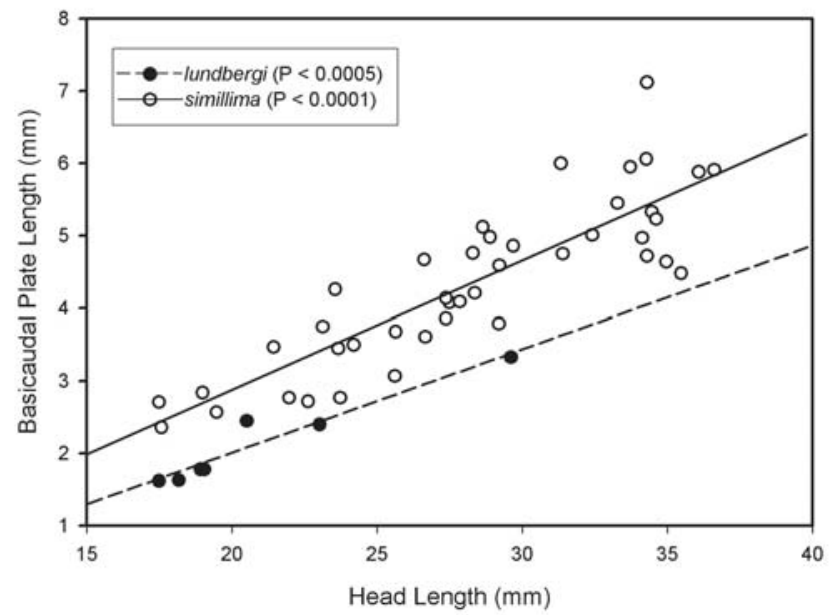

Fig. 11. Bivariate scatterplot and linear regression lines showing relationship between basicaudal plate length and head length in Loricaria lundbergi $\left(R^{2}=0.991, P<0.0001\right)$ and $L$. simillima $\left(R^{2}=0.939, P<0.0001\right)$. 
8.1-9.7\% SL. Eye moderately large, maximum orbital diameter $17.8-21.2 \% \mathrm{HL}$; iris operculum present, although inconspicuous in specimens collected from deep channel habitats of large rivers. Postorbital notch moderately developed and rounded in smaller specimens examined (76.6-103.6 mm SL); well developed and slightly angular in largest specimen examined (138.1 mm SL).

Entire body covered with dermal plates except for ventral surface of head anterior to branchiostegals, anterior median abdominal area, around bases of pelvic fins, and V-shaped area surrounding anus. Dermal plates on dorsum of body from snout tip to dorsal-fin origin with weakly to moderately developed odontode crests. Odontodes moderately developed on lateral margins of head from snout tip to opercle and along anterodorsal margin of orbit. In smaller specimens (76.6$103.6 \mathrm{~mm} \mathrm{SL}$ ), two prominent odontode crests originating at snout tip converging between nares, becoming divergent on frontals, continuing in parallel to posterior parieto-supraoccipital tip; odontode crests less conspicuous in largest specimen (138.1 mm SL). Dorsal and dorsolateral plates between pterotic-supracleithrum and dorsal-fin origin each with single prominent median crest. Lateral surface of exposed cleithrum with inconspicuous median keel of odontodes.

Upper lip narrow with numerous marginal fringe barbels, each simple, bifid, or trifid. Maxillary barbel short, even with or slightly longer than marginal fringe barbels on lower lip, with simple or bifid secondary barbels. Lower lip well developed with conspicuous median notch; surfaces covered with numerous elongate filaments; and marginal fringe barbels simple. Premaxillary teeth 2-4 on each side, each tooth consisting of slender stalk ending in enlarged bilobed crown; outer lobe small, rounded or conical; inner lobe large, rounded or conical. Buccal papillae behind premaxillary teeth short, about the length of premaxillary teeth, arranged in cluster of approximately 16 . Dentary teeth 4-8 on each side; less than half the length of premaxillary teeth; structure similar to that of premaxillary teeth except lobes usually shorter, more rounded.

Total plates in lateral series 33-34 (modally 33). Anterior 17-18 lateral plates with two parallel odontode keels widely separated, converging at midline on caudal peduncle; posterior (coalesced) lateral plates 15-17 (modally 15) . Post-anal plates 19-21 (modally 20). Lateral abdominal plates 6-8 (modally 7), rectangular and elongate. Posterior median abdominal area with polygonal plates, largest and most developed on pre-anal shield, becoming smaller and loosely joined anteriorly, ending with smaller plates concentrated in center with naked areas on either side between lateral abdominal plates; area covering pectoral girdle mostly naked, with isolated clusters of plates usually present near bases of pectoral fins posterior to gill openings (Fig. 4c).

Dorsal fin when depressed reaching eighth or ninth plate posterior to its origin; distal margin slightly concave when erected. Pectoral fin when depressed reaching seventh lateral plate posterior to cleithrum; distal margin straight to slightly concave when erected. Unbranched pelvic-fin ray (spine) longest, reaching to anterior third of anal-fin length. Anal fin when depressed reaching seventh plate posterior to its origin; distal margin convex when erected. Distal margin of caudal fin concave, upper unbranched ray produced into long filament broken in all specimens examined.

Color in alcohol. Ground color tan to pale yellow. In largest specimen (138.1 $\mathrm{mm} \mathrm{SL}$ ), dark brown blotches irregularly distributed on dorsal surface of head and trunk with five dark brown transverse bands on dorsum from middle of dorsal fin to caudal peduncle; blotches on head inconspicuous and transverse bands present, but faded in smaller specimens (76.6-103.6 mm SL). Dorsal surfaces of upper lip lightly sprinkled with melanophores in large specimen, without melanophores in smaller specimens. Ventral surfaces pale yellow or cream. Pectoral and dorsal fins heavily pigmented with melanophores; dorsal fin with dark pigment on basal and distal third, with contrasting lightly pigmented or pale band in center. Pelvic fins with faint melanophores on distal two-thirds of fin; opaque, hyaline or with light sprinkling of melanophores in smaller specimens. Anal fin opaque or hyaline. Caudal fin with solid dark brown band on distal half, distal corner of upper lobe clear.

Variation. A single specimen (AMNH 74474, $138.1 \mathrm{~mm} \mathrm{SL}$; Fig. 8) from rio Mawarinuma (upper rio Negro drainage) is larger and more boldly patterned than specimens from deep channel habitats of the rio Negro. The rio Mawarinuma specimen also has larger eyes and well developed iris operculum ( $v s$. slightly developed or inconspicuous in rio Negro specimens). This individual is identified as Loricaria lundbergi on the basis of abdominal plate arrangement, pigmentation, and plate counts, all of which are consistent with the remaining six specimens collected via bottom trawls from the deeper rio Negro habitats. A relationship between eye size and capture depth could not be demonstrated for L. lundbergi for lack of sufficient available material with data on capture depth (but see Discussion, below).

Sexual dimorphism. None observed.

Distribution and ecology. Loricaria lundbergi is known from geographically disparate localities in the rio Negro system (Fig. 6). Six specimens, including INPA 28854 (holotype, 103.6 mm SL), ANSP 178694 (1 c\&s, 76.8 mm SL), INPA 28855 (2, 76.6-80.4 mm SL), and ANSP 187412 (2, 84.2-92.4 mm SL) were collected in bottom trawls at depths ranging from 8 to $19 \mathrm{~m}$ and at distances of 75 to $150 \mathrm{~m}$ from the shoreline, about $5 \mathrm{~km}$ upstream of the mouth of rio Branco (J. G. Lundberg et al. unpubl. data). A single specimen (AMNH 74474, $138.1 \mathrm{~mm}$ SL) was collected in the rio Mawarinuma in the upper rio Baria drainage, a tributary of the rio Casiquiare in Venezuela. All collections of this species were made in black-water habitats. Stomach contents of a single dissected specimen (ANSP 
$178694,76.6 \mathrm{~mm} \mathrm{SL}$ ) collected in depths of 7.9 to $19.1 \mathrm{~m}$ contained aquatic insect larvae (order Diptera, family Chironomidae), sclerotized body parts of unidentified insect larvae, organic detritus and sand.

Etymology. In honor of Dr. John G. Lundberg, Curator and Chaplin Chair of Ichthyology, Academy of Natural Sciences of Philadelphia, for his leading role in the Calhamazon Project and many outstanding contributions to Neotropical ichthyology.

\section{Discussion}

This study reveals three new species of Loricaria, two of which (L. spinulifera and L. pumila) have several additional unique features not shared among known congeners and one (L. pumila) attains a smaller adult size than any other member of the genus. Specimens of Loricaria spinulifera and $L$. pumila from benthic trawl samples exhibit variation in eye size and development that is apparently influenced by depth (Fig. 5) and perhaps water clarity. This variation is most pronounced in L. pumila. For example, ten of eleven specimens of $L$. pumila from white waters of the lower rio Amazonas and Pará are pallid in color, with diffuse brown blotches and bands on the dorsum of the body and fins. Six of those specimens, from depths of 24 to $29 \mathrm{~m}$, have a marked reduction in eye size and the eyes have receded into the orbit to the extent that they are not visible from above (e.g., as in Figs. 3c and 7). Three other specimens collected at depths ranging from 4.3 to $17 \mathrm{~m}$ have distinctly larger eyes not receded into the orbits and are clearly visible from above. A single specimen collected via benthic trawl in clear waters of the lower rio Tocantins at 3 to $8 \mathrm{~m}$ has well developed eyes, a slightly developed iris operculum (absent in other ten specimens), and is more boldly pigmented. Similar variation in eye development and pigmentation is evident among specimens of $L$. spinulifera (Fig. 2 vs. 3a), particularly the reduction or absence of the iris operculum and faded or diffuse pigment patterns of specimens collected at greater depths. Although the relationship between eye size and depth could not be adequately tested for L. lundbergi due to small sample sizes, specimens collected via trawls in depths of 12-15 m had distinctly smaller eyes with reduced or absent iris opercula compared with the larger specimen from the rio Mawarinuma.

Many catfishes inhabiting deep river channels of South America are known to exhibit varying degrees of reduction to a complete loss of eyes and pigment (Lundberg \& Rapp PyDaniel, 1994). Such variation in eye development and pigmentation has been attributed to differences in isolation time in either a subterranean environment or dark epigean habitats (e.g., deep channels of turbid rivers) (Trajano, 2003). The three species of Loricaria described here exhibit variation ranging from the microphthalmic condition of specimens collected at greater depths to little or no apparent reduction in eyes and pigmentation of specimens collected in shallower habitats. These patterns suggest that some populations in- habiting deep river channels have persisted in low-light conditions long enough to develop certain features associated with subterranean environments.

Comparative material examined. The following specimens of Loricaria cataphracta (44), L. clavipinna (38), L. parnahybae (16) and L. simillima (119) were used in morphometric and meristic analyses. Loricaria cataphracta: NRM 18186 (3, 134.1-170.5 mm SL), Comte River, Cayenne Department, French Guiana; AMNH 214812 (1, 111.7 mm SL), Berbice River, Guyana; AMNH 214868 (3, 82.94-101.8 mm SL), Demerara River, Guyana; AMNH 215086 (2, 121.4 - 129.3 mm SL), Demerara River, Guyana; AMNH 215180 (1, 115.0 mm SL), Kora-Kora Creek (Atlantic dr.), Guyana; AMNH 215176 (1, 101.4 mm SL), Demerara River, Guyana; FMNH 53076 $(1,108.6 \mathrm{~mm}$ SL), Creek in Mora Passage (Waini and Barima River dr.),Guyana; ROM 66708 (2, 135.0-151.1 mm SL), Waini River, Guyana; ROM 66718 (3, 164.9 mm SL), Waini River, Guyana; ROM 66723 (2, 102.4-149.4 mm SL), Waini River, Guyana; ROM 66727 (2, 92.3-150.8 mm SL), Waini River, Guyana; ROM 66729 (1, $120.5 \mathrm{~mm}$ SL), Waini River, Guyana; ROM 66731 (1, $108.6 \mathrm{~mm}$ SL), Pomeroon River, Guyana; ROM 66732 (2, 139.2-194.1 mm SL), Waikerebi Creek (Waini and Barima dr.), Guyana; ZMA 106.233 (7, 88.6-106.5 mm SL), Sara Creek (Suriname dr.), Brokopondo District, Suriname; ZMA 106.230 (8, 250.6-280.3 mm SL), Marowijne River, Marowijne District, Suriname; USNM 225905 (2, 126.5-156.1 mm SL), Corantijn River, Nickerie District, Suriname; USNM 225906 (2, 138.11-158.91 mm SL), Corantijn River, Nickerie District, Suriname.Loricaria clavipinna: AUM 23780 (7, 92.3-177.5 mm SL), rio Acre (Purus-Amazonas dr.), Pando Department, Bolivia; AMNH 12615 (1, $159.8 \mathrm{~mm} \mathrm{SL})$, rio Embira (Jurua-Amazonas dr.), Amazonas State, Brazil; AMNH 12614 (3, 166.7-178.6 mm SL), rio Macaua (Purus-Amazonas dr.), Amazonas State, Brazil; ANSP 138863 (5, 141.0-170.7 mm SL), rio Amazonas, Loreto, Peru; INHS 55407 (1, 150.5 mm SL), rio Amazonas, Loreto, Peru; ANSP 176142 (1, $81.3 \mathrm{~mm} \mathrm{SL}$ ), rio Nanay (Amazonas dr.), Loreto, Peru; ANSP 176143 (1, 121.4 mm SL), rio Nanay (Amazonas dr.), Loreto, Peru; INHS 40389 (6, 126.4 mm SL), rio Nanay (Amazonas dr.), Loreto, Peru; INHS 40453 (1, $156.3 \mathrm{~mm}$ SL), rio Nanay (Amazonas dr.), Loreto, Peru; INHS 40468 (1, 157.4 $\mathrm{mm}$ SL), rio Nanay (Amazonas dr.), Loreto, Peru; INHS 44218 (5, 102.2-162.6 mm SL), rio Nanay (Amazonas dr.), Loreto, Peru; INHS 53748 (4, 88.3-173.88 mm SL), rio Nanay (Amazonas dr.), Loreto, Peru; SIUC 29902 (1, 107.6 mm SL), Loreto, Peru; ANSP 68665 (holotype, $138.5 \mathrm{~mm} \mathrm{SL}$ ), rio Ucayali (Amazonas dr.), Loreto, Peru. Loricaria parnahybae: AUM 20597 (7, 83.1-137.92 mm SL), rio Gurgueia (Parnaíba dr.), Piauí State, Brazil; NMW 44823 (paralectotype, $112.2 \mathrm{~mm}$ SL), rio Parnaíba, Piauí State, Brazil; NMW 44854 (lectotype, 102.2 mm SL), rio Parnaíba, Piauí State, Brazil; NMW 45098 (2, 126.5-140.2 mm SL), rio Parnaíba, Piauí State, Brazil; NMW 74917 (4 paralectotypes, 109.1-132.7 mm SL), rio Parnaíba, Piauí State, Brazil; MZUSP 37892 (1, $134.1 \mathrm{~mm}$ SL), rio Sambito (Parnaíba dr.), Piauí State, Brazil. Loricaria simillima: AUM 23637 (1, 219.8 mm SL), Lago Tumi Chucua (Madeira-Amazonas dr.), Beni Department, Bolivia; AUM 23721 (6, 110.4-217.0 mm SL), rio Beni (Madeira-Amazonas dr.), Beni Department, Bolivia; USNM 305807 (1, 214.2 mm SL), rio Beni (Madeira-Amazonas dr.), Beni Department, Bolivia; FMNH 55111 (1, 131.5 mm SL), rio Machupo (Mamoré-Madeira dr.), Beni Department, Bolivia; UMMZ 204971 (6, 205.6-224.7 mm SL), playa pond of rio Itenez (Mamoré-Madeira dr.), Beni Department, Bolivia; FMNH 107027 (1, 205.2 mm SL), rio Nareuda (Madeira- 
Amazonas dr.), Pando Department, Bolivia; FMNH 107029 (1, $185.3 \mathrm{~mm} \mathrm{SL}$ ), rio Tahuamanu (Madeira-Amazonas dr.), Pando Department, Bolivia; FMNH 107030 (1, 163.4 mm SL), rio Tahuamanu (Madeira-Amazonas dr.), Pando Department, Bolivia; INHS 73014 (1, $125.0 \mathrm{~mm} \mathrm{SL})$, rio Amazonas, Amazonas State, Brazil; MZUSP 56657 (2, 101.6-111.6 mm SL), rio Amazonas, Amazonas State, Brazil; MZUSP 57618 (1, 122.3 mm SL), rio Solimões (Amazonas dr.), Amazonas State, Brazil; CAS 6463 (1, 143.2 mm SL), rio Tocantins, Goiás State, Brazil; CAS 6430 (4, 135.1-160.8 mm SL), rio Tapajos, Pará State, Brazil; CAS 6451 (4, 127.6-133.9 mm SL), rio Tapajos, Pará State, Brazil; FMNH 59669 (3, 124.4-163.9 mm SL), rio Guapore (Madeira-Amazonas dr.), Mato Grosso State, Brazil; MCP 15755 (4, 215.7-235.9 mm SL), rio Paraguay (La Plata dr.), Mato Grosso State, Brazil; MCP 15805 (1, $178.7 \mathrm{~mm}$ SL), rio Paraguay (La Plata dr.), Mato Grosso State, Brazil; USNM 326340 (3, 105.0-131.2 mm SL), rio Paraguay (La Plata dr.), Mato Grosso State, Brazil; MZUSP 78791 (1, $179.1 \mathrm{~mm}$ SL), rio Jaurú (Paraguay-La Plata dr.), Mato Grosso State, Brazil; ANSP 178692 (3, 87.8-114.2 mm SL), rio Amazonas, Pará State, Brazil; CAS 6464 (2, 145.2-181.1 mm SL), rio Amazonas, Pará State, Brazil; FMNH 55112 (1, 163.8 mm SL), rio Amazonas, Pará State, Brazil; FMNH 111002 (1, 158.7 mm SL), rio Amazonas, Pará State, Brazil; NMW 46165 (6, 123.7-171.4 mm SL), rio Amazonas, Pará State, Brazil; MZUSP 57332 (1, 184.7 mm SL), rio Xingu, Pará State, Brazil; rio Paraná (La Plata dr.), MZUSP 21140 (2, 185.1-208.1 mm SL), Paraná State, Brazil; UF 100669 (1, $179.2 \mathrm{~mm}$ SL), rio Madeira (Amazonas dr.), Rondônia State, Brazil; MNRJ 27833 (3, 133.1-171.0 mm SL), rio Jiparaná (MariapeMadeira dr.), Rondônia State, Brazil; MCNG 33917 (1, 185.1 mm SL), rio Uraricoera (Branco-Negro dr.), Roraima State, Brazil; FMNH 104364 (2, 143.0-145.1 mm SL), rio Jivino (Napo-Amazonas dr.), Napo Province, Ecuador; BMNH 1880.12.8.77 (lectotype, 163.1 $\mathrm{mm} \mathrm{SL}$ ), rio Bobonaza (Marañon-Amazonas dr.), Pastaza Province, Ecuador; BMNH 1880.12.8.78 (paralectotype, 158.0 mm SL), rio Bobonaza (Marañon-Amazonas dr.), Pastaza Province, Ecuador; BMNH 1880.12.8.79 (paralectotype, $151.3 \mathrm{~mm} \mathrm{SL}$ ), rio Bobonaza (Marañon-Amazonas dr.), Pastaza Province, Ecuador; BMNH 1880.12.8.80 (paralectotype, $64.9 \mathrm{~mm} \mathrm{SL}$ ); rio Bobonaza (Marañon-Amazonas dr.), Pastaza Province, Ecuador; FMNH 70867 (1, $150.0 \mathrm{~mm}$ SL), rio Cusuimi (Napo-Amazonas dr.), Pastaza Province, Ecuador: AUM 35710 (1, 220.4 mm SL), Pirara River (BrancoNegro-Amazonas dr.), Guyana; AUM 35711(3, 71.9-90.7 mm SL), Yuora River (Branco-Negro-Amazonas dr.), Guyana; SIUC 47397 (1, 136.6 mm SL), Yuora River (Branco-Negro-Amazonas dr.), Guyana; UMMZ 208113 (1, $198.1 \mathrm{~mm} \mathrm{SL}$ ), rio Paraguay (La Plata dr.), Central Department, Paraguay; UMMZ 207830 (5, 170.1$272.5 \mathrm{~mm}$ SL), rio Aquidaban (Paraguay-La Plata dr.), Concepción Department, Paraguay; FMNH 52567 (2, 217.3-238.1 mm SL), rio Paraguay (La Plata dr.), Presidente Hayes Department, Paraguay; FMNH 55104 (2, 153.5-223.3 mm SL), rio Paraguay (La Plata dr.), Presidente Hayes Department, Paraguay; FMNH 55105 (1, 255.3 $\mathrm{mm}$ SL), rio Paraguay (La Plata dr.), Presidente Hayes Department, Paraguay; ROM 55695 (2, 106.9-129.7 mm SL), rio Ucayali (rio Amazonas dr.), Huánuco, Peru; ROM 55696 (1, 175.8 mm SL), rio Ucayali (rio Amazonas dr.), Huánuco, Peru; FMNH 111003 (4, 156.5-189.7 mm SL), laguna Rimachi (rio Amazonas dr.), Loreto, Peru; INHS 39968 (1, 217.7 mm SL), rio Itaya (rio Amazonas dr.), Loreto, Peru; INHS 43343 (1, $164.4 \mathrm{~mm} \mathrm{SL}$ ), rio Itaya (rio Amazonas dr.), Loreto, Peru; INHS 52729 (1, $135.1 \mathrm{~mm}$ SL), rio Maranon (Amazonas dr.), Loreto, Peru; INHS 54791 (2, 106.0-155.3 mm SL), rio Maranon (Amazonas dr.), Loreto, Peru; ANSP 138928 (6,
117.9-188.6 mm SL), rio Amazonas, Loreto, Peru; INHS 55407 (1, $150.5 \mathrm{~mm}$ SL), rio Amazonas, Loreto, Peru; INHS 53846 (1, 101.3 $\mathrm{mm} \mathrm{SL}$ ), rio Napo (Amazonas dr.), Loreto, Peru; INHS 54992 (1, $116.3 \mathrm{~mm} \mathrm{SL}$ ), rio Napo (Amazonas dr.), Loreto, Peru; USNM 301648 (3, 101.0-147.9 mm SL), rio Madre de Dios (MadeiraAmazonas dr.), Madre de Dios, Peru; USNM 302644 (2, 130.8$183.0 \mathrm{~mm} \mathrm{SL}$ ), rio Madre de Dios (Madeira-Amazonas dr.), Madre de Dios, Peru; USNM 326844 (1, 172.2 mm SL), rio Madre de Dios (Madeira-Amazonas dr.), Madre de Dios, Peru; USNM 326845 (1, $174.1 \mathrm{~mm} \mathrm{SL}$ ), rio Madre de Dios (Madeira-Amazonas dr.), Madre de Dios, Peru; USNM 327973 (1, 126.9 mm SL), rio Madre de Dios (Madeira-Amazonas dr.), Madre de Dios, Peru.

\section{Acknowledgments}

We thank the following individuals and institutions for loans of material and hosting museum visits: B. Brown and S. Schaefer (AMNH); M. Sabaj and J. Lundberg (ANSP); J. Armbruster (AUM); J. Maclaine and O. Crimmen (BMNH); D. Catania and T. Iwamoto (CAS); M.A. Rogers, P. Willink, and K. Swagel (FMNH); M. Retzer (INHS); D. Taphorn (MCNG); R. Reis (MCP); K. Hartel (MCZ); P. Pruvost and G. Duhamel (MNHN); P. Buckup (MNRJ); M. de Pinna (MZUSP); H. Wellendorf and E. Mikschi (NMW); E. Åhlander and S. Kullander (NRM); E. Holm and R. Winterbottom (ROM); B. Burr and J. Stewart (SIUC); R. Robins and L. Page (UF); D. Nelson (UMMZ); J. Williams, L. Palmer, S. Raredon, and S. Jewett (USNM); I. Isbrücker (ZMA); and D. Neumann (ZSM). This research represents a portion of a doctoral dissertation at Southern Illinois University at Carbondale. B. Burr provided invaluable support and guidance to MRT throughout graduate studies. This research was supported in part through grants to MRT, including a Field Museum Visiting Scientist Scholarship, Böhlke Award (Academy of Natural Sciences, Philadelphia), Ernst Mayr Award (Harvard University Museum of Comparative Zoology), Dissertation Research Award (Southern Illinois University), and the All Catfish Species Inventory (DEB-0315963). LRP participation in 1994 Calhamazon Expedition funded by National Science Foundation, Calhamazon Project, and INPA, Manaus. This manuscript benefited from the comments of two anonymous reviewers.

\section{Literature Cited}

Boeseman, M. 1971. The "comb-toothed" Loricariinae of Surinam, with reflections on the phylogenetic tendencies within the family Loricariidae (Siluriformes, Siluroidei). Zoologische Verhandelingen, 116: 1-56.

Covain, R. \& S. Fisch-Muller. 2007. The genera of the Neotropical armored catfish subfamily Loricariinae (Siluriformes: Loricariidae): a practical key and synopsis. Zootaxa, 1462: 1-40.

Covain, R., S. Dray, S. Fisch-Muller, \& J. I. Montoya-Burgos. 2008. Assessing phylogenetic dependence of morphological traits using co-inertia prior to investigate character evolution in Loricariinae catfishes. Molecular Phylogenetics and Evolution, 46: $986-1002$. 
Cox Fernandes, C., J. Podos \& J. G. Lundberg. 2004. Amazonian ecology: tributaries enhance the diversity of electric fishes. Science, 305: 1960-1962.

Douglas, R. H., S. P. Collins, \& J. Corrigan. 2002. The eyes of suckermouth armoured catfish (Loricariidae, subfamily Hypostomus): pupil response, lenticular longitudinal spherical aberration and retinal topography. Journal of Experimental Biology, 205: 3425-3433.

Ferraris Jr., C. J. 2007. Checklist of catfishes, recent and fossil (Osteichthyes: Siluriformes), and catalogue of siluriform primary types. Zootaxa, 1418: 1-628.

Isbrücker, I. J. H. 1981. Revision of Loricaria Linnaeus, 1758 (Pisces, Siluriformes, Loricariidae). Beaufortia, 31: 51-96.

Isbrücker, I. J. H. \& H. Nijssen. 1978. Two new species and a new genus of neotropical mailed catfishes of the subfamily Loricariinae Swainson, 1838 (Pisces, Siluriformes, Loricariidae). Beaufortia, 27: 177-206.

Isbrücker, I. J. H. \& H. Nijssen. 1992. Sexualdimorphismus bei Harnischwelsen (Loricariidae). Odontoden, Zähne, Lippen, Tentakel, Genitalpapillen und Flossen. Pp. 19-33. In: Harnischwelse R. Stawikowski (Ed.), Die Aquarien- und Terrarien- Zeitschrift Sonderheft.

Leviton, A. E., R. H. Gibbs, Jr., E. Heal, \& C. E. Dawson. 1985. Standards in herpetology and ichthyology: part 1. Standard symbolic codes for institution resource collections in herpetology and ichthyology. Copeia, 1985: 802-832.

Lundberg, J. G. \& L. H. Rapp Py-Daniel. 1994. Bathycetopsis oliveirai, gen. et sp. nov., a blind and depigmented catfish (Siluriformes: Cetopsidae) from the Brazilian Amazon. Copeia, 1994: 381-390.

Rapp Py-Daniel, L. H. 1997. Phylogeny of the neotropical armored catfishes of the subfamily Loricariinae (Siluriformes: Loricariidae). Unpublished Ph.D. Dissertation, University of Arizona, Tucson, 280p.

Rodríguez, M. S. \& A. M. Miquelarena. 2005. Una nueva especie de Loricaria (Siluriformes, Loricariidae) para la cuenca del rio San Francisco, Jujuy, Argentina. Anales de la Academia Nacional de Ciencias Exactas, Fisicas y Naturales, Buenos Aires 55: 139-149.

Schaefer, S. A. 1997. The neotropical cascudinhos: Systematics and biogeography of the Otocinclus catfishes (Siluriformes: Loricariidae). Proceedings of the Academy of Natural Sciences, 148: 1-120.

Trajano, E. 2003. Ecology and ethology of subterranean catfishes. Pp. 601-635. In: G. Arratia, B. G. Kapoor, M. Chardon \& R. Diogo (Eds.). Catfishes, v. 2. Science Publishers, Enfield, 844p.

Accepted September, 2008 Published September 30, 2008 